
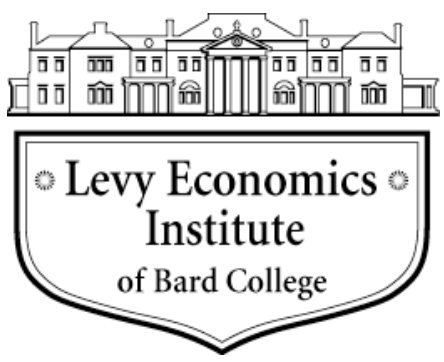

Working Paper No. 712

\title{
Shadow Banking and the Limits of Central Bank Liquidity Support: How to Achieve a Better Balance between Global and Official Liquidity
}

by

\author{
Thorvald Grung Moe* \\ Norges Bank \\ Levy Economics Institute of Bard College
}

April 2012

* Thorvald Grung Moe is a senior adviser in the Financial Stability wing of Norges Bank (the central bank of Norway) and a visiting scholar at the Levy Economics Institute.

The Levy Economics Institute Working Paper Collection presents research in progress by Levy Institute scholars and conference participants. The purpose of the series is to disseminate ideas to and elicit comments from academics and professionals.

Levy Economics Institute of Bard College, founded in 1986, is a nonprofit, nonpartisan, independently funded research organization devoted to public service. Through scholarship and economic research it generates viable, effective public policy responses to important economic problems that profoundly affect the quality of life in the United States and abroad.

Levy Economics Institute

P.O. Box 5000

Annandale-on-Hudson, NY 12504-5000

http://www.levyinstitute.org

Copyright (C) Levy Economics Institute 2012 All rights reserved 


\begin{abstract}
Global liquidity provision is highly procyclical. The recent financial crisis has resulted in a flight to safety, with severe strains in key funding markets leading central banks to employ highly unconventional policies to avoid a systemic meltdown. Bagehot's advice to "lend freely at high rates against good collateral" has been stretched to the limit in order to meet the liquidity needs of dysfunctional financial markets. As the eligibility criteria for central bank borrowing have been tweaked, it is legitimate to ask, How elastic should the supply of central bank currency be?
\end{abstract}

Even when the central bank has the ability to create abundant official liquidity, there should be some limits to its support for the financial sector. Traditionally, the misuse of the fiat money privilege has been limited by self-imposed rules that central bank loans must be fully backed by gold or collateralized in some other way. But since the onset of the crisis, we have seen how this constraint has been relaxed to accommodate the demand for market support. My suggestion is that there has to be some upper limit, and that we should work hard to find guidelines and policies that can limit the need for central bank liquidity support in future crises.

In this paper, I review the recent expansion of central bank liquidity support during the crisis, before discussing the collateral polices related to central banks' lender-of-last-resort and market-maker-of-last-resort policies and their rationale. I then examine the relationship between the central bank and the treasury, and the potential threat to central bank independence if they venture into too much risky balance sheet expansion. A discussion about the exceptional growth of the shadow banking system follows. I introduce the concept of "liquidity illusion" to describe the fragility upon which much of the sector is based, and note that market growth has been based largely on a "fair-weather" view that central banks will support the market on rainy days. I argue that we need a better theoretical framework to understand the growth in the shadow banking system and the role of central banks in providing liquidity in a crisis.

Recently, the concept of "endogenous finance" has been used to explain the strong procyclical tendencies of the global financial system. I show that this concept was central to Hyman P. Minsky's theory of financial instability, and suggest that his insights should be integrated into the ongoing search for a better theoretical framework for understanding the 
growth of the shadow banking system and how we can limit official liquidity support for this system. I end the paper with a summary and a discussion of some of the policy issues. I note that the Basel III "package" will hopefully reduce the need for central bank liquidity support in the future, but suggest that further structural reforms of the financial sector are needed to ease the tension between freewheeling private credit expansion and the limited ability or willingness of central banks to provide unlimited official liquidity support in a future crisis.

Keywords: Financial Regulation; Financial Stability; Monetary Policy; Central Bank Policy

JEL Classifications: E44, E52, E58, G28 


\section{INTRODUCTION}

The depth and length of the current financial crisis have been exceptional. The global financial system was close to a meltdown after Lehman filed for bankruptcy in September 2008. Central banks responded with unprecedented force and were able, for a time, to restore stability to financial markets. But as the crisis has dragged on, they have had to expand their tool kit and extend their support from single institutions to more general market support. Recently, some central banks have moved further into the uncharted territory of quantitative easing.

This transition from "lender of last resort" (LOLR) to "market maker of last resort" (MMLR) has been welcomed by many as a long-overdue adaptation of the classical LOLR role of the central bank to the realities of a modern market-based financial system (see Mehrling 2011). Domanski, Fender, and McGuire (2011) from the Bank for International Settlements note that "only currency issuing central banks have the ability to supply official liquidity in major currencies in an elastic manner, as during the recent crisis," and Kuttner (2010) states that "central banks will periodically be forced to intervene aggressively to ensure the functioning of financial markets."

The provision of an elastic currency has, over the years, certainly been one of the major - if not the major-functions of central banks. The Federal Reserve Act of 1913 stated that one of its key purposes was "to furnish an elastic currency." But the recent explosion of some central banks' balance sheets has also drawn criticism. Blinder (2012) criticizes the Fed's collateral policies during the crisis and expresses his doubts that Bagehot would have rated all of the pledged collateral as good. D. Thornton (2010) is concerned about the inflationary consequences of this massive expansion of central bank credit. Wray (2011) has criticized the decision-making process and the lack of transparency, while Johnson (2010) has accused central banks of bailing out insolvent institutions, and many have noted that quasi-fiscal support has been provided through generously priced bank support packages (e.g., Buiter 2008b).

In the following, I will not address these issues directly, but will instead focus on a more general, and in my view, more important theme: Are there any limits to this balance sheet expansion by central banks, and if so, what should the guiding principles be for central bank liquidity support in the future? I am also intrigued by the collateral policies followed by central 
banks during this crisis, and how they are constantly "tweaked" to fit the expanding financing needs of dysfunctional financial markets. This tension between the potential liquidity needs of the rapidly growing shadow banking sector and the capacity of central banks to provide elastic currency in a crisis is at the heart of this paper.

My intuition is that there must be some limit to how far central banks should go in supporting financial markets in a crisis, especially when much of the expansion prior to the crisis has been based on the "liquidity illusion" that markets were safe and would eventually be supported by central banks - almost for free. Even when the central bank has the ability to create abundant official liquidity, there should be some limits to its support for the financial sector. Traditionally, the misuse of the fiat money privilege has been limited by self-imposed rules that central bank loans should be fully backed by gold or collateralized in some other way. But since the onset of the crisis, we have seen how this constraint has constantly been relaxed to accommodate the demand for market support. As one market actor observed recently (with reference to the second long-term refinancing operation of the European Central Bank-ECB): "Potentially it can get very large...there is no upper limit."1 My suggestion is that there has to be some upper limit, and that we should work hard to find guidelines and policies that can limit the need for central bank liquidity support in future crises.

I start the paper with a short review of the recent expansion of central bank liquidity support during the crisis, from lender of last resort to market maker of last resort . I provide a highly stylized picture of the various policy interventions and review the terminology and operational practices being used. The recent transition from MMLR into the realms of unconventional monetary policy can be seen as an extension of traditional open market policy, a development that has brought monetary policy and policies to support financial stability closer together (Adrian and Shin 2009c). Second, I review the collateral policies related to central banks' LOLR and MMLR policies and their rationale. I show that there are inherent tensions between the need to collateralize all central bank operations and the expanding needs for liquidity support when markets crash, and I review different ways of reconciling these opposing objectives. Third, I discuss the relation between the central bank and the Treasury and the

\footnotetext{
${ }^{1}$ Jon Hilsenrath and Brian Blackstone, "Central banks diversify their arsenals," Wall Street Journal, January 26, 2012. http://online.wsj.com/article/SB10001424052970203363504577185151569908014.html
} 
potential threat to central bank independence if they venture into too much risky balance sheet expansion. I note that even if we consolidate the central bank and the Treasury, there should be some upper limit to the liquidity support for the expanding shadow banking system. Fourth, I present some facts about the growth of the shadow banking sector and introduce the concept of "liquidity illusion" to describe the fragility upon which much of the sector is based. I note that market growth has been based to a large extent on a "fair-weather" view that central banks will support the market on rainy days. This mispricing of official liquidity support, together with lax regulation, is a major reason behind the exceptional growth in these markets. Fifth, I review the theoretical framework for understanding the growth in the shadow banking system and the role of central banks in providing liquidity in a crisis. The interaction of private and public liquidity is still not fully understood (Domanski et al. 2011, p. 67), and our understanding of collateral policies is also weak. ${ }^{2}$ A recent report from the Committee on the Global Financial System (2011) uses the concept of "endogenous finance" to explain the strong procyclical tendencies of the global financial system. I show that this concept was central to Hyman Minsky's theories of financial instability and suggest that his insights should be integrated into the ongoing search for a better theoretical framework for understanding the growth of the shadow banking system and how we can limit official liquidity support for this system. I end the paper with a summary and a discussion of some policy issues. I note that the Basel III "package" will hopefully reduce the need for central bank liquidity support in the future, but suggest that further structural reforms of the financial sector will be needed to ease the current tension between free-wheeling private credit expansion and the limited ability or willingness of central banks to provide unlimited official liquidity support in a future crisis.

\section{THE BIG BALANCE SHEET EXPANSION}

The recent expansion of central banks' balance sheets has been so dramatic that the development deserves more attention. ${ }^{3}$ With the latest injection of reserve money, the central

\footnotetext{
${ }^{2}$ Stephen Williamson, "Discount Window Lending, Secrecy, and Stigma," Stephen Williamson: New Monetarist Economics (blog), December 3, 2011 http://newmonetarism.blogspot.com/2011/12/discount-window-lendingsecrecy-and.html.

${ }^{3}$ Gavyn Davies, “The Unprecedented Behaviour of the Central Banks.” Financial Times (blog), January 8, 2012
} 
banks of Europe, the UK, and the US have ventured into uncharted territory to resolve the ongoing crisis. Their initial response to the crisis in 2007 was based on the Bagehot rule that central banks should lend freely in a crisis on good collateral at a high rate of interest. But as more and more banks were affected by the Global Financial Crisis (GFC), central banks developed new approaches and took untraditional measures to contain the crisis. As policy rates approached the lower bound, they increasingly viewed balance sheet operations as a supplementary policy tool. The Federal Reserve decision to pay interest on reserves in October 2008 paved the way for a massive reserve injection that would have been unthinkable some years before. The ECB started with its "enhanced credit support" program in 2008, and subsequently moved into the much larger long-term refinancing operation (LTRO), which is ongoing. The Bank of England has likewise expanded its Asset Purchase Facility. But it all started back in 2007 when central banks acted as lenders of last resort during the GFC according to the Bagehot Rule. To fully understand how central banks' liquidity support has been stretched to the limits since then, a short review of that rule and its inherent shortcomings is required.

\section{The Traditional Lender of Last Resort Role (LOLR)}

\section{The Flexibility of the Bagehot Rule}

The Bagehot Rule was set forth by Walter Bagehot in his 1873 book, Lombard Street. He stated that central banks should lend early and freely (i.e., without limit) to solvent firms against good collateral and at high rates. Since then, this rule has been invoked whenever there has been a banking crisis. The rule, however, has been subject to widely different interpretations which have led to gradually more accommodative policies as the crisis has evolved. ${ }^{4}$

First, there is the recurrent issue of solvency. According to Bagehot, central banks should only lend to illiquid but solvent firms. But as de Grauwe (2011, pp.9-10) notes: "If solvency and liquidity crises can be separated, there is no need for a lender of last resort." Also, with more of the balance sheet subject to mark-to-market valuation, this distinction can be hard to draw in a crisis. As the Federal Reserve's Madigan (2009) notes: "Insolvency can cause

http://blogs.ft.com/gavyndavies/2012/01/08/the-unprecedented-behaviour-of-the-central-banks/\#axzz1mCcpRurj ${ }^{4}$ Some give Henry Thornton credit for the Bagehot rule, as it was extensively discussed in his 1802 book. Thornton gives the credit for the policy to Sir Francis Baring, who stated in 1797 that “...Bank of England had become the bankers bank, or 'the dernier resort."' 
illiquidity and vice versa - and the distinction blurs further in a financial panic." The decision to lend or not to lend will therefore involve a substantial element of judgment, especially if the central bank chooses to take a long term view of solvency. ${ }^{5}$

Second, it is equally hard to determine what constitutes "good collateral." Buiter (2008b, p.514) notes that the rule should be interpreted as lending freely "against collateral that will be good in the long run (even if it is not good today)," but determining long-run solvency is surely open to subjective interpretation. Bagehot advocated taking nontraditional collateral in a crisis; he even suggested that the Bank of England could accept railway stocks (which were not exactly a very safe asset at the time). And Buiter and Sibert (2007) go even further when they suggest that the Federal Reserve, if required, could "lend or repo against any collateral, including dead dogs and illiquid collateralized debt obligations." This may be going a bit far, but the Bagehot rule is certainly open to different interpretations.

Third, there is the recurrent discussion of whether lender of last support should be provided at a "penalty rate." "Many have argued that central bank support should only be provided at a penalty rate to limit moral hazard. For instance, Humphrey and Timberlake (2009, p. 16) argue that "borrowers should have relief in times of crisis, but they should be prepared to pay a price that implied a stiff penalty." Paul Tucker (2009) from the Bank of England has addressed this issue correctly, in my view:

Bagehot said that the rate should be "high." But since he wrote in the context of the Gold Standard and of domestic financial crises that were typically accompanied by external (or capital account) crises, his notion of a "high rate" was bound up with the central bank tightening monetary conditions to stem the outflows (of gold). But it is clear enough that, although he did not in fact talk of 'penalty' rates, the relevant measure for him was the rate charged by the central bank relative to that prevailing in the market in normal conditions, i.e., before a crisis breaks.

Still, many liquidity support facilities were provided at low rates during the crisis, and in some cases, even below the regular borrowing rate (primary credit rate in the US; see D. Thornton (2008). This has certainly been an intended side effect designed to help banks rebuild their

\footnotetext{
${ }^{5}$ Increasingly, central banks also consider the negative effects on other banks and the real economy in judging whether to provide liquidity support.

${ }^{6}$ For an extensive discussion of the policy and practice of the penalty rate, see Moe (2012).
} 
buffer capital, especially in the latter part of the crisis. ${ }^{7}$ Blinder $(2012$, p. 141) notes that "whether or not they charged a significant penalty rate varied from central bank to central bank, but the penalties normally weren't severe."

Lastly, central banks need to decide who should receive liquidity support, i.e., who should be their counterparties. Traditionally, central banks have only lent to banks in a crisis. Banks are the backbone of the monetary system, and as Tucker (2009, p. 3-4) notes, "in significant degree financial stability is about safeguarding the stability of private money (deposits held by households and firms with the banking system) relative to central bank money." To maintain parity between private deposit money and central bank (official) money is one of the key tasks of the central bank. "Absent that stability and confidence, the payments system and credit creation become severely disrupted, with big social costs" (Ibid.).

Table 1 illustrates this principle for the US financial system. Absent "exigent and extraordinary circumstances," the discount window (lender of last resort) is only open to banks, but with collateral requirements much wider than those for regular open market operations. All banks can apply for discount window loans, whereas only a small number of qualified primary dealers participate in open market operations (around twenty).

Table 1

\begin{tabular}{|c|c|c|}
\hline & Banks & Primary dealers \\
\hline Open market operations & $\sqrt{ }$ & $\sqrt{ }$ \\
\hline Discount window (LOLR) & $\sqrt{ }$ & \\
\hline
\end{tabular}

Note that lender of last resort loans in many other countries would only be available on a discretionary basis after the application had been scrutinized at the central bank. In the US, discount window loans are technically available at the discretion of the borrower; Buiter and Sibert (2007) call it a "LOLR light facility."

\footnotetext{
${ }^{7}$ Patrick Jenkins from the Financial Times recently noted (regarding ECB's LTRO) that: "With such a modest interest rate, it had also given them (the banks) an easy route to a nice profit margin." Some argue that rebuilding banks' balance sheets is required for them to start lending again. The same refinancing model was used back in the 1990s when a steep yield curve enabled US banks to rebuild capital. (See Patrick Jenkins, "Super Mario's bank funding scheme is no panacea," Financial Times, January 30, $2012 \mathrm{http} / / / \mathrm{www} . f t . c o m /$ intl/cms/s/0/e7a9830e-4b5e11e1-a325-00144feabdc0.html\#axzz1qbbtd356.)
} 
In the beginning of the crisis, central banks tried to apply the Bagehot rule, but with mixed results. This was partly because the rule is so open-ended, but also because banks were concerned about the consequences of applying for discount window loans. "If a bank worries that borrowing from the discount window will lead other banks to doubt its fundamental solvency, it may avoid the discount window even if it provides the cheapest funds available."

\section{The Stigma Problem of the Discount Window}

To address this problem, the Federal Reserve started to auction liquidity to banks. Starting in December 2007, there were twice-monthly auctions of fixed amounts (initially $\$ 20$ billion and $\$ 30$ billion, later increased to $\$ 75$ billion). The format of the auction (uniform or single-price, settlement after two days) helped to ensure anonymity and led to a price that was, on average, lower than other sources of funds (at the primary credit rate) (D. Thornton 2008). Between 50 to 90 banks participated in the first dozen auctions, many of them foreign-owned banking subsidiaries.

Cecchetti (2008) notes that "it may seem surprising that the Term Auction Facility would succeed, because all the auctions do is change the composition of the Fed's assets leaving the quantity unaffected." Before the crisis, the conventional wisdom was that such changes hardly mattered. ${ }^{9}$ But, since liquidity was so unevenly distributed during the crisis, the auction opened up liquidity for a large segment of banks that would otherwise not get loans directly from the primary dealers. In addition, the auction accepted collateral that was not considered eligible for open market operations, and the valuations were favorable.

As a supplementary policy to the Term Auction Facility (TAF), the Fed opened up currency swap lines with foreign central banks (CBLS) under the authorization of Section 14 of the Federal Reserve Act. These were to provide much needed relief to foreign banks running a dollar book outside of the US. Total loans under this and subsequent swap lines over time became a dominant part of the crisis response by the Federal Reserve (Felkerson 2011, p. 32).

\footnotetext{
${ }^{8}$ João Santos and Stavros Peristiani, "Why Do Central Banks Have Discount Windows?" Liberty Street Economics (blog), March 30, $2011 \mathrm{http} / / /$ libertystreeteconomics.newyorkfed.org/2011/03/why-do-central-banks-havediscount-windows.html.

${ }^{9}$ Cechetti refers to "Operation Twist" in the 1990s and foreign exchange sterilization, which seemed to have little effect at the time.
} 
Already at this point we can see the contours of facilities that would be implemented later: the widening of counterparties (but at this stage still only for banks, both local and foreign), the lengthening of maturities (but still quite short-term), and the wider collateral pool available for liquidity support.

\section{From LOLR via Market Maker of Last Resort to Quantitative Easing (QE)}

During the early part of 2008 it became evident that the official interventions in Europe and the US had not been enough. As Bear Sterns was rescued in March 2008, US Treasuries became increasingly scarce and the Federal Reserve decided to offer Treasuries to the primary dealers in exchange for well-rated (triple AAA/Aaa, but hard to trade) mortgage-backed securities (TSLF). Similar facilities were set up in many other countries to enable banks to re-engage with central banks on the basis of Treasury securities.

\section{Market Breakdown after Lehman}

When Lehman failed in September 2008 and AIG had to be rescued soon after, most financial markets became severely distressed and the risk of a worldwide systemic crisis was considered by many to be very real. Against this background many central banks initiated new and innovative lending facilities to provide liquidity to a wider set of counterparties, at much longer maturities and against a gradually much wider set of collateral. As we shall see, this was a step along the way to quantitative easing.

Madigan (2009, p. 174) provides the rationale for why the Fed, after decades of lending only to depository institutions, suddenly found it necessary to lend directly to broker-dealers:

Given the extent of the losses, and the uncertainty about their exact incidence, concerns about counterparty credit risk and lending firms' own solvency and liquidity increased dramatically. As a result, lending, arbitrage, and, more generally, market functioning broke down across a broad front. Without a liquidity provider of last resort, that breakdown in market functioning likely would have implied the disorderly failure of a number of primary dealers. Given their large size and interconnections within the financial system, that development would probably have cascaded across markets and institutions, with attendant severe adverse effects on credit availability and the economy. 
After the money market fund, Reserve Primary Fund, "broke the buck" on September 16, the Federal Reserve started intervening more directly in specific markets. As Adrian and Shin (2009a, p. 47) note: "The Fed's balance sheet was being used to directly replace the decline in balance sheet capacity of the financial intermediary sector." Since only central banks had "deep pockets" and market knowledge, they could credibly post buying and selling prices to restore market activity. In this way, they became the market makers of last resort (Buiter and Sibert 2007, p. 172). And as Buiter (2008b, p. 525) noted: "It would have been inefficient to privatize and decentralize the provision of emergency liquidity when there was an abundant source of free liquidity readily available."

\section{Exigent and Extraordinary Circumstances}

During 2008, the Federal Reserve pushed the rules for liquidity support in a crisis, from lending to depository institutions (TAF), to non-bank financial institutions (TSLF), to non-financial institutions (CPFF), to direct loans (Maiden 1, 2, and 3), and to credit support operations (Citi, BofA). The authority to undertake such lending was found in Section 13 (3) of the Federal Reserve Act. This section authorizes the Federal Reserve Board to make secured loans to individuals, partnerships, or corporations in "unusual and exigent circumstances" and when the borrower is "unable to secure adequate credit accommodations from other banking institutions."

When the Federal Reserve intervened to save Bear Stearns, former Fed Chairman Paul Volcker considered the support (to JP Morgan) "to extend to the very edge of its lawful and implied powers, transcending certain long embedded central banking principles and practices" (Volcker 2008). And Cecchetti (2008) noted that "the subsidy implicit in the loan to Bear Stearns is clearly a fiscal, not a monetary operation. The Federal Reserve is effectively acting as a fiscal agent for the Treasury." He was also concerned that "such use of the central banks' balance sheet for credit operations risks compromising the independence of the central bank if it becomes a regular occurrence."

Chairman Ben Bernanke (2009) defended the liquidity support in Congress, when he noted that:

The actions that the Federal Reserve and the Treasury have taken to stabilize systemically critical firms were essential to protect the financial system as a 
whole, and, in particular, the financial risks inherent in the credits extended by the Federal Reserve were, in my view, greatly outweighed by the risks that would have been faced by the financial system and the economy had we not stepped in.

And Madigan (2009) added that "had Bagehot been a member of the Federal Reserve Board, he most certainly would have approved such actions." 10

And as many have observed, all of these facilities were designed in close cooperation with the Treasury, and some even with their explicit backing (Term Asset-Backed Securities Loan Facility-TALF). After the Bear Stearns rescue, Secretary of the Treasury Paulson sent a letter to Governor Geithner of the NY Fed, confirming that “...if any loss arises out of the special facility ... the loss will be treated by the FRBNY as an expense that may reduce the net earnings transferred by the FRBNY to the Treasury General Fund" (Cecchetti 2008, p. 18). This position was later confirmed for all the three Maiden Lane facilities in the Joint Fed-Treasury Statement in April 2009:

In the longer term and as its authorities permit, the Treasury will seek to remove from the Federal Reserve's balance sheet, or to liquidate, the so-called Maiden Lane facilities made by the Federal Reserve as part of efforts to stabilize systemically critical financial institutions.

As noted before, it is hard, if not impossible, to judge whether an illiquid institution is also insolvent in the midst of a crisis. You would certainly not want to determine its solvency on the basis of "fire sale" prices, but at what prices should you then judge its solvency? Sometimes the intervention by the central bank can stabilize the situation and lead to a good equilibrium, but it is always hard to tell a priori.

Here it is sufficient to state that if the central bank lends to a truly solvent, but illiquid bank, it should expect to get repaid, and there should in principle not be any limits to its liquidity support (Buiter 2007).

\section{Funding and Sterilization Policies}

In the beginning of the crisis, most central banks were inclined to sterilize all the liquidity facilities. In the US, the Federal Reserve would "fund" the initial facilities by selling off its

\footnotetext{
${ }^{10}$ A legal opinion from the New York law firm Sullivan and Cromwell concluded in 1991 that the Fed could lend directly to security firms in emergency situations under Article 13 of the FRA (Schwartz 1992, p. 63).
} 
Treasury holdings. In this way, the money that was paid to an illiquid bank would not result in an increase in base money, i.e., the money banks keep on account with the central bank. As noted above, all interventions would then "only" shift the composition of the Fed's balance sheet, but not its size. The same policy was followed by most other central banks, but with certain variations. ${ }^{11}$

The Federal Reserve could initially use its large stock of Treasury securities to sterilize the liquidity impact of its support facilities. But after Lehman and AIG, the Fed allowed some excess reserves to accumulate. To assist in the "mopping up" of reserves, the Treasury started its Supplementary Financing Program, which was designed to assist the Fed in managing its balance sheet (Stella 2009, p.21-22). The Treasury issued short-term debt (Cash Management Bills) and deposited the proceeds with the FRB. But there was a growing sense within the Fed that a change in operating procedures for monetary policy was required, and this led to the decision in October 2008 to start paying interest on reserves. ${ }^{12}$

There was also a gradual realization among policymakers (especially in the US) that the central bank did not necessarily have to sterilize all the liquidity support. ${ }^{13}$ This was the transformation from the "Phase I" liquidity facilities that were gradually repaid and wound down in the US during early 2009, to "Phase II" facilities and the shift in policy toward liquidity provision with the intent of leaving excess reserves with the banks.

This shift in monetary policy was partly motivated by the "zero lower bound"- the fact that policy rates had been lowered close to zero. ${ }^{14}$ But it was also a realization that there were other transmission channels of monetary policy that could be activated to get banks to lend to small and medium-sized businesses (SMBs). By separating the decision to fix the policy rate

\footnotetext{
${ }^{11}$ Since central banks execute monetary policy differently, it can sometimes be difficult to compare their monetary policies. In the initial phase of the financial crisis, this was apparent, as some central banks had regular facilities in place that were flexible and could easily be adjusted to the crisis, whereas others had to introduce new facilities. See BIS (2007) for an early overview. Amstad and Martin (2011) provide a more recent comparison.

${ }^{12}$ See Goodfriend (2011) for an excellent overview of Fed policies during the crisis, including the decision to pay interest on reserves, and Keister and McAndrews (2009) for a good discussion of why banks are holding excess reserves. Grad, Mehrling, and Neilson (2011) also give a good overview with balance sheet illustrations.

${ }^{13}$ This change in perspective was not as abrupt in many other countries that had already implemented a "corridor system" of monetary policy; see Keister and McAndrews (2008).

${ }^{14}$ Technically, central banks could pay a negative interest rate, e.g. charge banks for keeping funds on account. Irving Fisher had a proposal for "stamp money" in the 1930s where your money would lose value if not used within a certain date (Fisher 1933).
} 
from the decision of reserve balances, central banks could now use two instruments to pursue different goals (monetary and financial policy). This shift in perspective has in part underpinned the exceptional growth in the central bank balance sheets that we have observed recently.

\section{National Differences in Quantitative Easing}

Central banks have traditionally performed monetary policy by either outright transactions (direct purchase of a security) or repurchase operations (repos), e.g., a combination of a cash transaction today and a forward agreement that reverses the transaction at a specified future date. Since the "new" policies of quantitative easing (QE) involve the temporal swap of central bank money for a specified set of eligible collateral, all forms of QE are really just traditional open market operations with a significantly longer maturity and a significantly wider collateral pool (Cagler et. al. 2011, p.5). The significant difference from Phase I lender of last resort liquidity support and even the later market maker of last support is the new policy of not sterilizing the liquidity injections. By leaving the excess reserves on the books of the banks, authorities hope for an additional "bang for the buck" from their monetary policy stance (in addition to the zero interest rate policy-ZIRP). This policy change has resulted in the exceptional growth in central bank balance sheets.

Due to the different initial operating procedures for monetary policy and local variations in the availability of collateral, there are some important differences in the way QE is executed among the major central banks. The Federal Reserve has conducted its large-scale asset purchase program (LSAP) with outright purchases of long term Treasuries and agency debt, whereas the ECB is conducting long-term repos in its long-term refinancing operation (LTRO) facility. The UK is conducting its QE through a special investment vehicle, the Asset Purchase Facility that operates with full indemnity from the Treasury, which receives all profits and will bear any losses (Chadha 2010). In addition, the Federal Reserve has initiated a new asset purchase program called the maturity extension program (MEP) that will purchase longer term Treasuries and fund the program via sales of short term Treasuries. This program will not affect the reserve position of the Federal Reserve or its member banks. ${ }^{15}$

\footnotetext{
${ }^{15}$ For details on the various US and UK asset purchase programs, see Meaning and Zhu (2011). Note that the MEP
} 
The ECB's version of QE is the "long-term refinancing operation." The facility has actually been in existence since 1999, but in the early phase only for short-term refinancing (three months). In December 2011, the ECB (ECB 2011) announced that it would extend three year loans to participating banks against an expanded collateral pool, and with the interest rate based upon the average of the overnight rate during the loan period. Over 500 banks borrowed 489 billion euros in the first LTRO. In the second LTRO on February 29 the ECB lent another 530 billion euros. The collateral pool was substantially expanded in February, giving national central banks more discretion in approving additional credit claims as collateral (ECB 2012).

Due to the December QE, the ECB's assets were equivalent to nearly 30 percent of eurozone GDP by the end of 2011. That is much larger than the Federal Reserve's portfolio, which at \$2.9 trillion was about 19 percent of US GDP. The Fed's balance sheet, on the other hand, has been growing much faster. It has more than tripled in size since 2007, while the ECB's has more than doubled in size.

\section{Is QE Working?}

Meaning and Zhu (2011) conclude that the UK and US asset purchase programs have had noticeable effects so far. The immediate impact on bond yields has been strong, although it is tapering off. There was also a sizeable reduction in corporate yields. And the programs also seemed to have had a stabilizing effect on financial markets. Yellen (2011) notes that their programs have "reduced the cost of credit to consumers and businesses, raised asset prices that boost household wealth and spending, and had a moderate impact on the foreign exchange value of the dollar that provides support to net exports." Davies (2012) is more skeptical and notes that it is not evident that "future injections of QE will have the same benign effects, either in scale or even in direction."

On balance, the asset purchases must be judged on a cost-benefit basis. Davies (2012) notes that: "In the absence of these injections, private banks would have been forced to deliver their balance sheets in order to remain liquid, and in all probability, some would have gone

\footnotetext{
is a new version of the "operation twist" that was tried under the Kennedy administration, with mixed results.

${ }^{16}$ Gavyn Davies, "Is QE Still Working?" Financial Times (blog), February 8, 2012

http://blogs.ft.com/gavyndavies/2012/02/08/is-qe-still-working/\#axzz1mCcpRurj
} 
bankrupt, causing contagion throughout the financial sector and the economy at large." ${ }^{\prime 17}$ Others, including D. Thornton (2010), are concerned that "the current level of excess reserves could create a massive increase in the money supply and long-run inflation well above the implicit inflation objective of two percent if banks should significantly increase their lending or investing."

The scale of the current balance sheet expansion is huge and unprecedented. The upside is a recovery with slow, but steady employment growth and banks that may start to finance real investment. The downside is continued market distress and falling asset prices that will gradually undermine the solvency of banks and other financial companies, including pension funds. In the downside alternative, central banks could find their collateral values shrinking, forcing them to increase haircuts and cut down on loans to banks - or continue to extend credit, but on constantly weaker collateral. That would be a real dilemma.

Blinder (2012) notes that "unconventional monetary policies will be more prevalent and important in the future, and thus it becomes important to understand which types of unconventional policies work best under which circumstances." It is too early to tell if QE has been a success. But as the Financial Times (2012a) recently noted, there should be "alternative ways to put money into the hands of the most credit-starved: small businesses and households, not big companies with more cash than they know what to do with. Marginally lower gilt yields will not achieve this. It is time to move from talk to action on credit easing or yet more imaginative ways to throw central bank money around."

Fiscal policy will always be an alternative way to get the money (more) directly to those that are most in need. As Chairman Marriner Eccles of the Federal Reserve noted before Congress in 1935: "Monetary policy in a depression is like 'pushing on a string." The choice may therefore be between huge balance sheet expansions with uncertain effects and huge budget deficits with more certain effects.

\footnotetext{
${ }^{17}$ Gavyn Davies, “The Unprecedented Behaviour of the Central Banks.” Financial Times (blog), January 8, 2012 http://blogs.ft.com/gavyndavies/2012/01/08/the-unprecedented-behaviour-of-the-central-banks/\#axzz1mCcpRurj
} 


\section{THE COLLATERAL SQUEEZE}

The rapid expansion of central bank balance sheets could have been limited if the Bagehot Rule for "good collateral" had been adhered to. It would have meant higher funding costs for banks, but the integrity of the collateral policy would have been maintained. Instead, many central banks have chosen to accommodate the growing need for liquidity support by relaxing their collateral requirements. ${ }^{18}$ Since the unsecured funding markets have been more or less shut down since Lehman, and many banks have had to turn to their central banks for funds, this has created an enormous squeeze among banks to find enough eligible collateral.

As we noted in the previous section, central bank credit should, according to the Bagehot Rule, be extended freely in a crisis, but against good collateral. But since valuation of collateral is necessarily subjective, especially if one takes (correctly) a forward looking valuation approach, the value of collateral for central bank loans becomes rather fluid. And since the value of collateral is normally low in a crisis when the need for central bank credit is high, there is an inherent tension between the need for emergency credit and the strictures of the collateral rules.

This tension has led to some uneasiness among central bankers, since the crisis has exposed the time-inconsistency of their strict pre-crisis collateral rules. Zorn and Garcia (2011) from the Bank of Canada note that: "The benefits of a flexible collateral policy were demonstrated during the crisis, but how flexible should collateral policies be? How much risk can or should a central bank take on? How can operational readiness to accommodate this flexibility be balanced with the costs, particularly when extraordinary events are, by definition, infrequent?" Why have rules if they are relaxed when they are most needed? As we shall see, there are inherent tensions between the need to collateralize all central bank liquidity facilities and the expanding needs of the market for emergency liquidity in a crisis, and there are no easy ways of reconciling these two objectives.

\section{Central Bank Collateral Policies}

Credit Only Against Collateral

\footnotetext{
${ }^{18}$ For an excellent review of the collateral policies of the ECB, Federal Reserve and Bank of England before and after the financial crisis, see Cheun et al. (2009).
} 
It is a widely held belief among central bankers that credit should only be granted to private sector counterparties against collateral. This limits the central bank's exposure to financial loss and lessens the need for counterparty credit assessment (Cheun 2009, p. 9).${ }^{19}$ Central banks are public sector institutions and therefore need to act prudently in order to preserve taxpayers' money. Should the central bank incur large losses, it could risk losing credibility in maintaining price stability.

Some see a strict collateral policy as a safeguard against unlimited money growth. The scarcity of eligible collateral should, in theory, act as a brake on central bank credit, thus acting as a substitute for gold or other precious metals in preserving the integrity of the fiat money system. Central banks should only be able to extend credit as long as it is backed by something "solid." ${ }^{20}$ The issuance of claims against oneself is, in principle, indefinitely augmentable and therefore not well-qualified as collateral. The same goes for government credit, as they could then pledge self-issued debt as collateral for loans from the central bank.

This view of government financing is reflected today in many central bank laws that explicitly prohibit central bank financing of the public sector. The rationale for this position has been to limit the potential for inflationary "deficit financing" and to strengthen central bank credibility, a key ingredient for achieving monetary policy effectiveness. A recent IMF working paper thus recommends as a first best rule that "central banks should not finance government expenditure. The central bank may, however, be allowed to purchase government securities in the secondary market for monetary policy purposes" (Jácome et. al. 2012).

The European Union (EU) has embedded this policy in its Treaty (Article 101), where it states that the ECB is prohibited from extending "overdraft facilities of any other type of credit facility to" or "purchase debt instruments from ... EU institutions or bodies, central governments, regional, local or other public authorities, other bodies governed by public law, or public undertakings of Member States." But, as Buiter and Sibert (2005, p. 5) noted: "Despite the Treaty ban on direct financing by the Eurosystem of member governments (i.e., no purchases of debt in the primary market), the Eurosystem could, if it wished to do so, bail out

\footnotetext{
${ }^{19}$ This rationale for central banks' collateral policy became more important as many central banks spun off the supervisory function to preserve monetary independence, especially during the 1990s.

${ }^{20}$ See Lehmbecker (2008, p. 24-26) for a statement of the German Property School of Economics' view on collateralized money.
} 
member governments by outright purchases of their debt in the secondary market. This would not violate the letter of the Treaties and the Protocols, but it would certainly violate the spirit." Some would argue that secondary market purchases are acceptable because someone else ("the market") has then given the debt instrument its "seal of approval." This makes the purchase by the central bank more acceptable and acts as a "safety vale" against pure monetization of government debt. But as Buiter and Sibert note, this is indeed a fine line, and in practice it may not make much of a difference.

\section{Market and Banking Sector Structure Impacts on Collateral Policy}

Whereas central bankers can agree on the need to preserve their independence and resist demands from politicians for monetary financing of the government, there are considerably more variations in their views and not the least in their practices when it comes to collateral policies. $^{21}$

Although the collateral requirements are frequently included in a central bank's statutes, the central bank itself normally decides what constitutes eligible collateral. This can vary between central banks due to legal tradition, market structure, banking structure, monetary policy operating procedures, payment system infrastructure and the economic situation of the currency area. Collateral that is considered "adequate" by one central bank could well be rejected by another. At first glance, this may seem strange, especially since one would expect central bankers to agree on such an important parameter of monetary policy. But as we shall see, there are reasonable arguments for the differences. But this, and the fact that the subject has not been researched much, ${ }^{22}$ also makes it hard to figure out when some central banks have stretched the meaning of "good collateral" too far.

If we take a brief look at the collateral policies of the ECB, the Federal Reserve, and the Bank of England, there are some basic legal differences: The ECB cannot discriminate between public and private issuers and has therefore chosen a wide collateral universe. The lack of a well-developed euro bond market was also a factor in the decision to accept private sector loans

\footnotetext{
${ }^{21}$ See Cheun et al. (2009) for further details.

${ }^{22}$ See Chailloux et al. (2008) for a notable exception!
} 
as eligible collateral. ${ }^{23}$ The Federal Reserve has traditionally maintained a "Treasuries only" policy for its monetary operations, whereas it has a distinctly different and much wider collateral pool for its discount window operations (although this facility was not used much before the crisis). The Bank of England has no legal restrictions on its collateral policy, but maintained a "Gilt only" policy up to year 2000, when the collateral universe was expanded (due to the Y2K transition) to include foreign sovereign bonds.

Changes in operating procedures for monetary policy also influence the type of collateral accepted. The ECB needs a lot of collateral for its temporary market operations, estimated to be around 40 percent of its balance sheet in 2007 (Cheun p. 17). In contrast, fine-tuning operations by the Federal Reserve have been very small in comparison (around 3 percent of its balance sheet in 2007), and the need for collateral consequently smaller. In addition, the Federal Reserve has maintained a huge stock of Treasury paper on its balance sheet (almost 90 percent) that enables it to fine-tune with outright sale and purchases of "Treasuries only." The scale of the Bank of England's market operations are somewhere in between, and have mostly been conducted with government paper.

The structure of the banking sector also plays a role in the design of central banks' collateral policies. The ECB can, in principle, conduct market operations with all depository institutions in the EU (around 1,700 in 2008). In practice, the number of counterparties is somewhere between 300 to 400 banks. Since their pools of collateral vary a lot, the ECB has to offer credit against a wide range of collateral. The Federal Reserve, in contrast, performs its open market operations with a very small number of "primary dealers" (around 20), whereas its discount window is, in principle, open to all the 7,000 or so member banks. ${ }^{24}$ The Bank of England has, in comparison, conducted their market operations with a small subset of banks"the clearing banks." Before the crisis, there was no formal discount window at the BoE.

The payment system infrastructure and specifically the design of the central bank settlement system (i.e., if it is a real time gross settlement—RTGS—system only, or a

\footnotetext{
${ }^{23}$ According to Chailloux et al. (2008, p. 11) the preference of the Bundesbank of accepting "commercial bills" as collateral for its monetary operations prior to the establishment of the ECB may also have influenced the ECB policy.

${ }^{24}$ For an overview of the eligible collateral at the Fed's Discount Window, see their web site for "Discount Window and Payment System Risk Collateral Margins Table.”
} 
combination of net and gross settlement systems) also have an impact on the collateral policy. Both the ECB and the Bank of England maintained the same collateral policies for their temporary market operations, marginal credit facilities, and intraday credit, whereas the Federal Reserve, as noted above, used a much narrower collateral policy for its market operations. And for their intraday collateral policy they now maintain a dual policy of either collateralized lending or uncollateralized lending for a small fee (50 bp) (Reserve Board 2011, Section V). ${ }^{25}$ As the size of the intraday market relative to the central bank's balance sheet is also very different (10 percent for the Fed and the ECB in 2007, compared to 50 percent for the BoE), there is an obvious need for more eligible collateral in the collateral-intensive RTGS systems.

\section{Changes in Collateral Policies during the Crisis}

The three central banks reviewed above did respond differently to the financial crisis, partly due to timing and nature of the crisis, but also due to their different operating procedures pre-crisis. ${ }^{26}$

\section{Central Bank Liquidity Insurance}

Cheun et al. (2009) compare the policy responses of the ECB and the Federal Reserve and rank the liquidity insurance element they provided according to five criteria: range of counterparties, interest rate, size of operations, range of eligible collateral, and maturity. They note that the new facilities developed by the Federal Reserve could, at least at first sight, appear to be more accommodative than the Eurosystem repo operations: the range of collateral was broader (including unsecuritized residential mortgage loans and consumer credit loans), the range of counterparties was larger, and the interest rate was lower than comparable ECB facilities (25 basis points over the policy rate compared with 75 basis points in the ECB marginal facility at the time). In addition, two of the Fed programs went beyond the scope of the Eurosystem's measures, i.e., the commercial paper funding facility (CPFF) facilitated direct purchases of commercial paper from the issuers, whereas the TALF program involved non-recourse loans to

\footnotetext{
${ }^{25}$ This is actually a departure from the universal agreement that all central bank lending should be "fully" collateralized.

${ }^{26}$ For details of their crisis responses, see Cheun et al. (2009); Fisher (2011) for details on the response of BoE, and Goodfriend (2011) for a broad overview of the Fed's response to the crisis and the policy challenges that remains.
} 
investors, and thus represented a quasi-outright purchase of securities in an effort to revive the asset-backed securities (ABS) market (Cheun et al. 2009, p. 38).

However, they note that there were a number of special nuances to the Eurosystem's temporary operations that distinguished them from the Fed's discount window operations, and that these nuances made them almost as accommodative (if not more so) (Ibid., p. 38-39). First, the Eurosystem had one facility for all eligible counterparties (whereas the Fed operated several "windows" for different groups of counterparties); second, the Eurosystem refinancing operations were available at a longer maturity; third, due to the high level of transparency of the collateral framework, banks and issuers knew in advance whether their bonds would be eligible; ${ }^{27}$ and fourth, the Eurosystem allowed the use of "own use" ABS (this was not considered acceptable collateral by the Federal Reserve). In addition, they note that many of the US facilities were expected to wind down automatically, since they were priced at a premium over normal interest rate spreads. And finally, they note that the relaxation of collateral standards in discretionary operations by the Fed was temporary, whereas the broad range on collateral and the lengthening of maturities in the Eurosystem "is a permanent feature of its framework" (Ibid., p.39).

As we know, polices have changed in both central banks since this ECB paper was written in 2009. It is still interesting to note, however, (1) how the pre-crisis operational framework influenced the need for changes to the collateral framework when the crisis hit, and (2) that their collateral frameworks seemed to drift apart as the ECB decided to maintain its very broad collateral pool, whereas the Fed let its crisis facilities run down (before it embarked on its recent policy of quantitative easing). ${ }^{28}$

\section{Pros and Cons of a Broad Collateral Policy}

Is it possible to draw any general conclusions about what constitutes sufficient or adequate collateral? With such large variations in legal traditions, market and banking structures, monetary policy operating procedures, payment system infrastructure design, and the economic

\footnotetext{
${ }^{27}$ The Eurosystem publishes a daily update of all 45,000 individual securities that are eligible for refinancing operations (p.38).

${ }^{28}$ It should be added here that emergency loans to individual banks against a broad set of collateral is delegated to the National Central Banks of the Eurosystem, subject to ECB approval (ECB 2012).
} 
conditions between different countries, one should probably expect there to be quite different collateral frameworks. This leads one to reflect on the mantra that "all central bank lending should be collateralized" and to think about what that statement actually means in practice. As we noted earlier, even valuing a single piece of collateral is difficult and can be subject to abrupt valuation changes. If, in addition, we cannot decide on a common set of eligible collateral, it is hard to put that statement forward as the "pivotal element of a theory of central banking" (Lehmbecker 2008, p.26).

Cheun et al. (2009, p. 39) note that the broad collateral framework of the ECB was able to cope better with the crisis, and few adjustments were required. They also note that a broad framework brings with it certain challenges. First, there is a liquidity risk when the ECB accepts collateral from markets that are seriously impaired. Hence, a broad collateral framework requires intensive monitoring and risk controls. Second, there may be a risk of price distortions in the longer run, as the central bank's preference for illiquid assets may lead to an oversupply of such assets and a consequent impact on credit allocation. Third, accepting "own use" securities could reduce incentives for banks to tap other funding markets. And finally, Cheun et al. (2009, p.40) note that:

... a broad collateral framework risks not creating the appropriate incentives for banks to manage liquidity risk properly, allowing them to divest of highly liquid assets such as government bonds in exchange for illiquid assets.

Paul Fisher (2011) from the Bank of England argues that a broad, but still differentiated collateral policy may be better to deal with this problem of adverse selection. The Bank of England's new policy is similar to the Federal Reserve's, with monetary operations conducted on a fairly narrow set of collateral, but with gradually widening pools becoming available. If the banks could post relatively illiquid collateral for monetary policy operations, Fisher argues that they “...will have an incentive to exploit that premium. That would mean that the central bank's monetary policy operation could become a regular source of funding (and profit) for the firm. This can matter if, for example, it creates distortions in demand for those lower quality assets." 
The Bank of England's solution is to only accept high quality collateral for its monetary operations, ${ }^{29}$ i.e., those issued by sovereign issuers of the highest credit quality and that are expected to remain liquid in all but the most extreme circumstances. There is then a wider collateral pool available for more long-term financing (the indexed long-term repo-ILTR), where firms can bid to get reserves against their narrow or wider collateral sets at different prices. And then there is an even wider range of collateral eligible for the Bank's discount window facility (DWF), with prices depending on the quality of the collateral posted; the less liquid, the higher the fee. The bank uses a combination of haircuts (to protect the balance sheet) and fees (to discourage use except under stressed conditions). The table below shows the four different categories of collateral eligible for BoE operations in the new sterling monetary framework.

\begin{tabular}{|c|c|c|c|c|c|}
\hline & $\begin{array}{l}\text { Intraday } \\
\text { liquidity }\end{array}$ & $\begin{array}{l}\text { Operational } \\
\text { Standing } \\
\text { Facilities }\end{array}$ & $\begin{array}{r}\text { Short-tem } \\
\text { OMOs }\end{array}$ & $\begin{array}{r}\text { Indexed } \\
\text { long-term } \\
\text { OMOS }\end{array}$ & $\begin{array}{l}\text { Discount } \\
\text { Window } \\
\text { Facility }\end{array}$ \\
\hline $\begin{array}{l}\text {-evel A 'narrow collateral' } \\
\text { (eg high-quality sovereign debt) }\end{array}$ & $\checkmark$ & $\checkmark$ & $\checkmark$ & $\checkmark$ & $\checkmark$ \\
\hline $\begin{array}{l}\text { evel B wider collateral' } \\
\text { (eg liquid and high quality } \\
\text { mortgage and corporate bonds) }\end{array}$ & $x$ & $x$ & $x$ & $\checkmark$ & $\checkmark$ \\
\hline $\begin{array}{l}\text { Level C (eg illiquid transferable } \\
\text { securitised loans and mortgages) }\end{array}$ & ) & $x$ & $x$ & $x$ & $\checkmark$ \\
\hline $\begin{array}{l}\text { evel D (eg own-name } \\
\text { securitisations and covered bonds } \\
\text { and loans) }\end{array}$ & ds, & $x$ & $x$ & $x$ & $\checkmark$ \\
\hline
\end{tabular}

In addition, the bank can accept any collateral it can value and risk manage for emergency liquidity assistance (ELA) outside of the publicly available (standing) operations.

This overview shows that collateral policies vary a lot between central banks, both in regular operations and during crises. Based on their review of the collateral policies of the Bank of England, the Federal Reserve and ECB during the crisis, Cheun et al. (2009, p. 10) concluded

\footnotetext{
${ }^{29}$ Short-term repo open market operations (STR OMO) and Operational Standing Facilities (OSF).
} 
that "the interpretation of 'adequacy of collateral' given by different central banks depends on the design of the operational framework and external factors shaping the supply and demand of collateral. The choice of collateral is a residual decision [italics added] after the other, arguably more important, decisions are made."

It follows that central banks' collateral policy cannot be set in stone independent of legal, external, and internal factors, and that attempts to do so (or pretend that one can derive a common global standard) are misplaced and will lead to time-inconsistent policies.

\section{Collateral Challenges}

The breakdown of the unsecured interbank market after the crisis, the growth of central bank borrowing, and additional concerns over collateral safety in segregated accounts after the MF Global bankruptcy have led to a collateral squeeze among banks. The steep growth in central bank financing has led to further tightening as central banks do not recirculate posted collateral back into the market (as is done by the major banks through rehypothecation). ${ }^{30}$ This has led banks to become more creative in their collateral polices and to find ways to post "cheap" collateral with central banks. This development poses some new challenges for central banks.

\section{Gresham's Collateral Law}

With the markets depending on several trillion dollars' worth of repo funding, the recent scramble for eligible collateral has led to a "collateral crunch." Some have observed that "collateral may soon become the key determining factor behind which financial institutions remain profitable and which don't." ${ }^{\prime 31}$ For a given borrowing rate, banks would try to post the lowest quality acceptable collateral at the central bank because better quality collateral has alternative uses with better returns. This type of behavior is well known, as observed by an ECB executive board member (Chailloux et al. 2008, p.5):

\footnotetext{
${ }^{30}$ Higgins and Klitgaard (2011) noted that European banks had already borrowed (in the ECB) against the bulk of their eligible collateral (before the announced LTRO); see Matthew Higgins and Thomas Klitgaard, "Central Bank Imbalances in the Euro Area," Liberty Street Economics (blog), December 21, 2011 http://libertystreeteconomics.newyorkfed.org/2011/12/central-bank-imbalances-in-the-euro-area.html.

${ }^{31}$ Izabella Kaminska, "2010: The Year of Collateral.” ft.com/alphaville (blog), September 10, 2010 http://ftalphaville.ft.com/blog/2010/09/10/340146/2010-the-year-of-collateral/.
} 
Quite understandably, (central bank counterparties) have economized on the use of central government bonds which has been often almost the only collateral counterparties could still use in interbank repo markets. Instead they have brought forward less liquid collateral...including ABSs, for which primary and secondary markets have basically dried up.

Chailloux et al. (2008, p. 32) observe that market participants in the Eurosystem seem to exhibit such "adaptive" behavior, with a clear trend toward deploying lower quality assets over a period of several years. This behavior is particularly marked for those central banks with the most accommodative collateral standards. They call this "Gresham's law of collateral." 32 At the same time, according to Chailloux et al., "...the use of bank bonds as collateral has surged, outpacing their share in the pool of eligible collateral, and spurring concerns of manufactured collateral." They note that (Ibid., p.33):

One loophole could consist for bank A to issue large amounts of bonds to be placed with bank B, while bank B would issue matching amounts to bank $\mathrm{A}$, both using the thus acquired securities to access central bank liquidity provision. Banks facing similar LIBOR funding costs could thus "create" an easy and "costfree" access to central bank liquidity.

By facilitating this type of "collateral manufacturing," central bank policies prepared the way for the buildup of leverage before the crisis in the banking and the shadow banking system. Banks could use their high quality collateral to obtain repo-financing, thereby providing pledgeable collateral for the daisy-chains of rehypothecation in the shadow banking system. By running an accommodative collateral policy before the crisis, many central banks supported the excessive market growth that they eventually had to validate during the crisis with even more lax collateral standards. The recent changes in the incentive system for bank borrowing at the Bank of England is one way to address this adverse selection problem, although it is hard to implement when the banking sector is struggling, as is the case now in many countries.

\section{Procyclical Haircuts}

Haircuts are the amount of collateral a borrower places with a lender over and above the face value of the borrowing. Central banks use haircut policies to protect their balance sheet. Since

${ }^{32}$ Gresham's law is often stated as "bad money drives out good money," whereas in this case it would be "illiquid, low quality collateral drives out liquid, high quality collateral." 
collateral values vary with the economic cycle, so do haircuts. This can amplify financial market procyclicality. Haldane (2011) notes that "haircuts exhibit a rather dramatic procyclicality over the course of the crisis." This was particularly pronounced before the crisis when low haircuts made it cheaper for banks to mobilize collateral to finance borrowing, adding momentum to the upward pendulum swing of asset prices and credit growth. A recent Bank for International Settlements (BIS) report (CGFS 2010, p. vii) describes the behavior in this way:

Competitive pressures have a strong influence on securities financing haircuts and the range of eligible collateral for such transactions in good times. In bad times, tightening is often implemented first through revisions to counterparty credit limits, while increases in haircuts tend to follow later.

This strong procyclicality represents a dilemma for central banks. Since their own risk control policies are based on the same principles as market participants, they risk amplifying the cycle even further by increasing margins and tightening lending standards during a crisis. ${ }^{33}$ Such a strict collateral policy is obviously counterintuitive, as central banks are supposed to rescue the markets in a crisis. But it illustrates well the tensions between "finance-based" collateral guidelines and "macro-based" crisis management policies.

Chailloux et al. (2008, p. 41) note that "the fact that central banks' propensity to take risk is not aligned with the market's rising risk aversion in a time of crisis is in fact a highly desirable feature from a financial stability perspective. This can help to stem the excesses of the credit cycle, and provide some funding alternatives when conditions in the market become tight and build an illiquidity discount into some asset prices."

However, such countercyclical behavior can only be useful over time if neutrality is restored in normal times. "Otherwise, central banks would increasingly ease their collateral requirements and end up undermining public confidence in the soundness of their balance sheet, potentially weakening the trust in money" (Ibid., p.41).

\section{Time Inconsistency Problem}

Central banks are faced with a real problem. If they insist on only highly liquid assets as collateral for liquidity support in a crisis, some solvent banks with liquidity problems may fail.

\footnotetext{
${ }^{33}$ See Cossin et al. (2002) for an analysis of consistent haircut policies over the cycle.
} 
If such failures have the risk of creating financial instability, the central bank may decide to lend anyway against a wider set of collateral. In doing so, they will weigh the immediate impact of a bank failure against the higher long-term probability of failure as a result of saving a failing bank now (moral hazard).

If the banks perceive the central bank's action correctly, they may well hold less of the good collateral and more of the bad (i.e., Gresham's law). And the central bank may not be able to stick to their announced strict collateral policy, just as the bank suspected. As Paul Tucker noted $(2009$, p. 6): "In other words, a central bank policy of lending against only the best assets is likely to prove time inconsistent [italics added] when it comes to the crunch.",34

This dilemma could be reduced or resolved more easily if banks were smaller. This could be facilitated by the new process of "living wills" to prepare for a future crisis, but there is still a long way to go. Alternative ways to resolve banking crises could also reduce the systemic fallout from a stricter collateral policy during a crisis. ${ }^{35}$ Hannoun (2012) notes that "the way the Nordic countries dealt with their banking crisis in the early 1990s is a role model for others."

If the resolvability of banks is not improved, for example through the "living will" process, central banks may be forced to relax their collateral policies to accommodate the need for crisis liquidity support in the future. This would be unfortunate, as it would strengthen the perception of unlimited central bank intervention and result in even more moral hazard.

\section{A Short Historical Note on Collateral Policy}

The "real bills doctrine" claimed that central bank money creation would self-regulate if based only on self-liquidating, good quality commercial claims. This would support the real economy and avoid inflation. Despite severe criticism from, among others, H. Thornton (1802), the doctrine survived and was embedded in many central bank laws. Eligible collateral was based on the idea that central bank money should support the "real economy." The Federal Reserve

\footnotetext{
${ }^{34}$ Bindseil and Lamoot (2011) support a broad collateral base during crisis, but they suggest much stronger incentives against misuse, including a supplementary liquidity measure of "distance to fire sale" (DFS).

${ }^{35}$ Schwartz (1992, p. 62) notes that "the Penn Central episode fostered the view that bankruptcy proceedings by a large firm created a financial crisis, and that if possible, bankruptcy should be prevented by loans and loan guarantees: this was the "too big to fail" doctrine in embryo."

${ }^{36}$ See Borio et al. (2010) for an overview of the way the Nordic banking crisis was resolved.
} 
Act incorporated the doctrine in the "elastic currency" concept. However, when the Depression hit in the early 1930s, Congress had to change the law so that the Federal Reserve could use Treasury paper to accommodate the huge need for emergency liquidity.

After the Second World War, the supply of Treasury paper was plentiful and this enabled the Federal Reserve to stick with its "Treasury only" policy. This policy was challenged, however, by the anticipation of budget surpluses in the US in the mid-1990s. This development led the Federal Reserve and also some central banks in other countries with strong budget positions to consider broadening their collateral pool for monetary policy. As the change-over from the year 2000 emerged, all central banks had to consider the same issue for their payment systems, and after "Y2K," the collateral pools remained wider for many (including the Bank of England).

This short history is just to remind us that the availability of collateral, the macroeconomic situation, and the specific national context do play a role in the development of central bank collateral policies. So it may be too much to expect universal principles - if there are none.

\section{CAN CENTRAL BANKS GO BROKE?}

The degree of central bank intervention in this crisis has been historically unprecedented. ${ }^{37}$ Many observers have noted that much of the liquidity support has been direct or semi-direct fiscal support. This could potentially put the solvency of central banks at risk. But can central banks actually go broke? And should their balance sheets be the limiting factor for liquidity support in a crisis? These issues have profound implications not only for the financial strength of central banks, but also for their future independence.

\section{Quasi-Fiscal Actions during the Crisis}

Many have observed that the scale and nature of the crisis support from central banks went beyond the traditional liquidity support for solvent institutions prescribed by Bagehot. Former

\footnotetext{
${ }^{37}$ See Stella (2009) for an excellent discussion of the exceptional growth of the Federal Reserve balance sheet during the crisis and steps that could be taken to bring it back to "normal."
} 
central banker Andrew Sheng (2011) is especially critical of the way central banks were "hijacked" into providing fiscal support during the GFC:

During the GFC, central banks became the lender of last resort, the market maker of last resort, but also the bank-loss underwriter of last resort, specifically when they took toxic assets onto their balance sheets. By doing so, central banks have become non-elected fiscal agents, undertaking quasi-fiscal obligations on behalf of the public in the name of financial stability. This violates the principle of no taxation without representation. Furthermore, there are no clear guidelines on who should be bailed out and who should not be, and why some of the prime offenders of market discipline should have been bailed out, whilst smaller institutions have become collateral damage.

Stephen Cecchetti (2008, p. 18) from the BIS is also critical of the way the Federal Reserve was conveniently used to provide loans for bank rescues: "The subsidy implicit in the loan to Bear Stearns is clearly a fiscal, not a monetary operation. The Federal Reserve is effectively acting as the fiscal agent for the Treasury."

Jaime Caruana, chairman of the BIS, sums it up when he notes that "many central banks feel distinctly uncomfortable about the longer-term implications of such large balance sheets. At some point, the capital of the central bank could be put at risk."

However, as we have shown, determining that liquidity support during a crisis is, in fact, solvency support — which in principle should be dealt with by the treasury — is difficult, if not impossible. This raises some interesting issues for central banks, not just about the potential risk to their balance sheets if such support leads to losses. It also has implications for the division of labor between monetary policy and financial policies, and the role of the central bank as a market maker of last resort.

\section{Does Negative Central Bank Equity Matter?}

Contrary to common sense, central banks can operate with negative equity indefinitely. Only if the economy should enter a strong deflationary spiral, or if the central bank cannot cover foreign liabilities by creating domestic currency, would it need additional capital. A recent example is the central bank of Chile that lost its equity during the banking crisis in 1982 with a rescue bill of 30 percent of GDP. Initially, the cost was born entirely by the central bank, but in 1987 the government made a partial capitalization. Then the issue was not discussed again until 2006, 
when another five year capitalization plan was approved by the Congress (Stella and Lonnberg 2008, p. 14).

Buiter (2006) has noted that huge central bank losses typically arise in the midst of a banking crisis when central banks with "short-term deep pockets" provide risk-laden credit and thereafter hope to be recapitalized by the treasury, the state agency with "long-term deep pockets."

Large currency operations (sterilizations, e.g., buying foreign exchange in exchange for local currency) has also led some central banks to incur large losses that threatened their solvency, as the foreign exchange was invested in low yielding US Treasuries, while the local banks got a much higher rate on their domestic deposits. And recently, the Swiss National Bank made headlines after its huge currency interventions led to large losses. But the acting Chairman of SNB recently insisted that

$\ldots$ in the short run, central banks can bear heavy losses and even go into negative equity if necessary. In the case of the SNB there is no legal need to recapitalize the bank immediately. We will simply recapitalize the bank through future profits. $^{38}$

Central banks have unique income-earning potential, primarily through their seigniorage income. Stella (2009) notes that the Federal Reserve has made a profit every year since 1916. Due to its huge income generating capacity it could easily double its capital in one year. Not all central bank balance sheets have the same income generating capacity, but in general this is not their biggest concern. The bigger threat is posed by the loss of confidence and the lack of public backing for their core missions that can result from potential huge losses.

\section{Threat to Central Bank Independence?}

Could large liquidity support operations be a threat to central bank independence? Goodfriend (2011) thinks so, and notes that

A healthy democracy requires full public disclosure and discussion of the expenditure of public funds. The congressional appropriations process enables Congress to evaluate competing budgetary programs and to establish priorities

\footnotetext{
${ }^{38}$ Gillian Tett and John Gapper, "Jordan vow to continue SNB intervention," Financial Times, February 2, 2012.
} 
for the allocation of public resources. Hence, the Fed — precisely because it is exempted from the appropriations process - should avoid, to the fullest extent possible, taking actions that can properly be regarded as within the province of fiscal policy and the fiscal authorities.

But this position is based on the assumption that it is clear, a priori, that the liquidity support considered contains an element of fiscal support. But determining this ahead of the intervention is the challenge, as we have noted above.

Buiter and Sibert (2007) take another, characteristically colorful view of the central bank's role in a crisis:

[a] credit crunch and liquidity squeeze is instead the time for central banks to get their hands dirty and take socially necessary risks which are not part and parcel of the art of central banking during normal times when markets are orderly. Making monetary policy under conditions of orderly markets is really not that hard. Any group of people with IQs in three digits (individually) and familiar with (almost) any intermediate macroeconomics textbook could do the job. Dealing with a liquidity crisis and credit crunch is hard. Inevitably, it exposes the central bank to significant financial and reputational risk. The central banks will be asked to take credit risk (of unknown) magnitude onto their balance sheets and they will have to make explicit judgments about the creditworthiness of various counterparties. But without taking these risks the central banks will be financially and reputationally safe, but poor servants of the public interest.

This is probably a good description of what actually happens in the midst of a chaotic crisis on a late Friday evening. It does not mean that we should not attempt to draw a brighter line between "credit policy" and "'monetary policy" (to use Goodfriend's terminology), but that it may be difficult in practice.

Goodhart (1999, p. 348) takes a rather relaxed view about the central bank's balance sheet when he notes that "what stands behind the liabilities of the central bank is not the capital of the central bank, but the strength and taxing power of the State."

Still, the boundaries between the central bank and the treasury can sometimes get blurred, even in countries with independent central banks. Stella (2009, p. 21) notes that during the height of the crisis, the Federal Reserve received support from the Treasury in conducting "market operations" to mop up all the surplus liquidity generated by their interventions. ${ }^{39}$ Such

${ }^{39}$ The Supplementary Financing Program, see discussion on page 14 above. 
close cooperation is not common and could potentially undermine the ability of the central bank to conduct its independent monetary policy.

Stella (2009, p. 48) therefore suggests a clearer demarcation between the central bank function of monetary policy and the newly created role of market maker of last resort. He suggests that this latter function could be performed by an independent agency outside the central bank, but with sufficient fiscal backing from the State. Such an entity could be named “the Market Liquidity Maintenance Corporation" (MLMC). It would be active in the capital markets, just as the central banks have been active in money markets. And the risk and profits of the MLMC would clearly be on the fiscal accounts - thereby avoiding potential conflict with monetary operations. ${ }^{40}$

The large crisis interventions and huge balance sheet expansions have clearly raised a host of new issues that are not fully understood yet. As Hannoun (2012, p. 20) observes, "The line between monetary and fiscal policy becomes blurred when the central bank continuously engages in balance sheet policies. Exiting from their unconventional balance sheet polices as soon as circumstances permit would be an important step for central banks to restore a clearer boundary vis-à-vis the fiscal domain."

But perhaps the boundaries cannot be so neatly restored. History shows that central bank structures have varied over time in response to the prevailing political and financial environment. Ugolini (2011) notes that: "On the whole, historical evidence suggests that the efficiency of any solution (concerning both organizational forms and monetary policies) crucially depends on the sustainability of the institutional arrangement backing them. ... Therefore, current organizational structures should not be seen as set in stone."

The same is the case for the implementation of government deficit monetization. In the long history of sovereign borrowing, periods of predominantly direct recourse to financial markets have alternated with periods of debt monetization the latter being the norm in times of market dysfunctionality. As a result, monetization should not necessarily be seen as evil, but rather as an option to be subjected to a benefit-cost assessment - in the light, of course, of the constraints imposed by the institutional arrangements in force. (Ibid.)

\footnotetext{
${ }^{40} \mathrm{He}$ notes that an alternative structure could see the function reside in either the Fed or the Treasury, but with a separate governance structure.
} 
And he concludes that "central banks should not merely defend the status quo: as one connoisseur pointed out during another period of great economic transformation, "the cardinal virtue of the central banker is not conservatism in technique, but rather a disposition to discover novelties and to be versatile in technique" (Sayers 1949, p. 211).

\section{Joint Treasury-Central Bank Capacity for Liquidity Support}

Some would argue that the distinction between the treasury and the central bank is artificial, and that we would get a better feel for the economic reality if we consolidate the two balance sheets. ${ }^{41}$ Then it becomes obvious that the central bank cannot go broke, as long as it is supported by the state. As Buiter (2008, p. 11) notes: "The central bank-treasury team is naturally, indeed umbilically, linked in conventional nation states with a single national central bank and a single national treasury."

The joint statement by the Federal Reserve and the Treasury in March 2009 (Board of Governors 2009) reaffirms this symbiosis (in the US) when it noted that the Treasury "in the longer term and as its authorities permit" would seek to "remove from the Federal Reserve's balance sheet, or to liquidate" significant facilities related to the efforts to stabilize systemically critical financial institutions. $^{42}$

However, this does not imply that the State should underwrite any liquidity support operation or provide a totally elastic currency in all (crises) circumstances. Removed from all the central bank jargon of collateral and Bagehot rules, it becomes easier to see that the state needs to evaluate any liquidity support based on a traditional cost-benefit analysis. This would enable it to decide whether to bail out large "too big to fail" (TBTF) banks, let them go bankrupt, or nationalize them (as was done in the Scandinavian banking crisis) (Borio, Vale, and von Peter 2010). ${ }^{43}$

\footnotetext{
${ }^{41}$ Friedman (1948) observed that the few central banking functions needed in his "ideal" monetary system could be performed by an office in the Treasury! See also Lerner (1943) and Wray (1998) for a functional finance view.

${ }^{42}$ The so-called Maiden Lane facilities related to the handling of Bear Sterns, Lehman, and AIG in 2008.

${ }^{43}$ FDIC conducts a sort of cost-benefit analysis when it determines resolution strategies for failed banks. However, their "least cost analysis" is rather narrow and limited to what is the best option for the FDIC only, and not for the society as a whole. The "systemic exemption clause" can be invoked to provide for a broader analysis, but due to time constraints, this clause frequently led to "bailouts" to avoid the systemic consequences of unplanned closures.
} 
The Federal Reserve (Board of Governors 2011b) has claimed that their liquidity support during the crisis was well-considered and helped stabilize the financial system at a critical point in time. In addition, they note that "the emergency loans and other assistance have generated considerable income for the American taxpayers." But, earning a decent return on the loan is different from getting the upside when the market is dead and nobody else is willing to put in the capital to continue operating the bank. As DeLong (2011) observes:

In the fall of 2008, counting the Fed and the Treasury together, a peak of 90 percent of Morgan Stanley's equity - the capital of the firm genuinely at riskwas US government money. ... When you contribute equity capital, and when things turn out well, you deserve an equity return. ...Thus I do not understand why officials from the Fed and the Treasury keep telling me that the US couldn't or shouldn't have profited immensely from its TARP [troubled asset relief program] and other loans to banks.

What we can conclude so far is that central banks can, in principle, provide unlimited public liquidity support in a crisis without concern for their balance sheets. ${ }^{44}$ It does not follow that this is a desirable policy. Given the growth in the shadow banking system, it may not be a wise policy for a combined central bank-treasury to support every dysfunctional market with huge liquidity injections. As Hannoun (2012) notes: "When central banks give the impression that they stand ready to do 'whatever it takes,' and hence offer unpriced insurance, moral hazard risk arises. Over time, this can lead to ever greater leverage and financial fragility."

The huge expansion in central banks' balance sheets is unprecedented, but manageable. Experiences from other central banks indicate that it may take years or even decades to return to normal. It would hardly be desirable in the current situation for central banks to volunteer even more liquidity support, even if this elastic currency is fully backed by the state. It is important to figure out if we can draw a "bright line" for future liquidity support, and where that line should go. Intuitively, the state should not be held responsible for all transactions in the expanding shadow banking system, even when banks are involved.

\footnotetext{
${ }^{44}$ Except for central banks in a currency union.
} 


\section{SHADOW BANKING AND CENTRAL BANK POLICIES}

The growth of the shadow banking system poses new challenges for central banks. Innovation and technological developments have led to rapid credit growth outside the banking system. As Sheng (2011) notes: "Financial engineering was the channel whereby credit became turbocharged." Increased securitization, leverage and re-pledging of collateral all led to a credit boom that eventually collapsed into the "Global Financial Crisis." Central banks reacted forcefully to prevent a new depression. But the unprecedented scale of liquidity support required has also led some to question the limits of such intervention. Sheng (2011) claims that "the financial crisis was the inevitable outcome of the fiat money feedback loop without a hard budget constraint."

A recent report from the Committee on the Global Financial System (2011, p. 29) suggests that after the crisis, we now need "a consistent international policy framework for addressing global liquidity." A key feature of such a framework will be "interventions by institutions with the ability to supply official liquidity in an elastic manner and in potentially very sizeable amounts." The question is whether central banks can and should continue to backstop the rapid growth of private credit outside the banking system.

\section{The Growth of Shadow Banking}

Shadow banking is defined as "credit extension outside of the banking system" (FSB 2011b). It includes entities such as hedge funds, money market funds, pension funds, insurance companies, and to some extent the large custodians such as Bank of New York and State Street Bank. Shadow banks typically fund themselves with securities lending transactions, i.e., use (and reuse) of the collateral they post with banks. Investment banks may conduct much of their business in the shadow banking system, but they are not shadow banks themselves.

The shadow banking system makes up 25 to 30 percent of the total financial system (FSB 2011b) and was a major contributor to the GFC. ${ }^{45}$ Krugman (2009) has noted that: "As the shadow banking system expanded to rival or even surpass conventional banking in importance, politicians and government officials should have realized that they were re-creating the kind of

${ }^{45}$ See Gorton and Metric (2010) for a short account of the role of shadow banks in the crisis. 
financial vulnerability that made the Great Depression possible - and they should have responded by extending regulations and the financial safety net to cover these new institutions."

This largely unregulated sector was worth about $\$ 60$ trillion in 2010 , having grown from an estimated \$27 trillion in 2002, according to the FSB (2011b).

\section{"Traditional” Shadow Banking}

The term "shadow banking" was coined by Paul McCulley (2007) of PIMCO when he noted that,

unlike regulated real banks, who fund themselves with insured deposits, backstopped by access to the Fed's discount window, unregulated shadow banks fund themselves with un-insured commercial paper, which may or may not be backstopped by liquidity lines from real banks. Thus, the shadow banking system is particularly vulnerable to runs - commercial paper investors refusing to re-up when their paper matures, leaving the shadow banks with a liquidity crisis - a need to tap their back-up lines of credit with real banks and/or to liquidate assets at fire sale prices.

He identified the birth of the shadow banking system with the development of money market funds in the 1970s - fund accounts that functioned largely as bank deposit accounts, but were not regulated as banks. These funds rose rapidly in the 1980s, from under $\$ 100$ billion in 1980 to almost $\$ 2$ trillion by 2000 (Gorton and Metrick 2010, p. 6). By the end of 2008, their size had doubled to almost $\$ 4$ trillion! They offer a bank-like product and almost instant access while pretending to be as safe as bank deposits. That this was not so became clear when the Reserve Primary Fund "broke the buck" in September 2008. This subsequently led to a massive run on the whole sector and new liquidity facilities by the Federal Reserve.

Today the shadow banking system has grown to include much more than the money market funds. Pozsar et al. (2010, p. 7) define shadow banks as "financial intermediaries that conduct maturity, credit, and liquidity transformation without access to central bank liquidity or public sector credit guarantees." In their classic report on the shadow banking system in the US, they estimated the sector to be around $\$ 16$ trillion in the first quarter of 2010, down by around $\$ 4$ trillion since the financial crisis. 
Shadow banking today comprises all the steps required to transform a loan into a "liquid" deposit. These steps can be performed by different actors, rather than as in the old days, where all steps were done within a traditional bank. Pozsar et al. classify seven steps involved in the shadow banking process: (1) loan origination; (2) loan warehousing; (3) ABS issuance; (4) ABS warehousing; (5) ABS CDO issuance; (6) ABS “intermediation;" and (7) wholesale funding. And as they note (p. 13), "the shadow banking system decomposes the simple process of deposit-funded, hold-to-maturity lending conducted by banks into a more complex, wholesale-funded, securitization-based lending process that involves a range of shadow banks." A major driver in the growth of the shadow banking system has been the transformation of the largest banks since the early-1980s from low return on equity (RoE) utility banks that originated loans and held them until maturity, to high RoE entities that originate loans in order to warehouse and later securitize and distribute them. By leveraging up through securitization, the bank could increase their RoE, apparently without risk. The problem was that in the process banks were fabricating new assets with dubious quality just for the sake of increasing their balance sheets (Adrian and Shin 2009a, p. 12). In the process, their underwriting capacity was undermined as they relied more and more on rating agencies and collateral values in the loan process. $^{46}$

Pozsar (2011, p. 24) explains the fabrication of triple-A securities with the increased demand for safe and liquid instruments from large private "cash pool" investors. These investors will frequently hold substantial amounts of cash, or they will "reverse maturity transform" 47 to get the required cash position, but do not want to be exposed to unsecured bank deposits. With a limited amount of government paper and much of it absorbed by foreign official agencies, the shadow banking sector responded to this challenge by creating (seemingly) safe, short-term liquid instruments. Pozsar sees the development of the shadow banking system as "an evolutionary response to the safety and counterparty diversification preferences of wholesale

\footnotetext{
${ }^{46}$ Minsky noted (in 1986, p. 261): "If bankers put the emphasis on the collateral values rather than the expected cash (from business), a fragile financial system emerges because loan viability depends on expected market values of the assets pledged."

47 "Reverse maturity transformation is due to portfolio allocation decisions, the peculiarities of modern portfolio management and the routine lending of securities for use as collateral. This reverse maturity transformation occurs in spite of the long-term investment horizon of the households whose funds are being managed" (Pozsar and Singh 2011, p. 4).
} 
cash pools and a structural deficit of short-term government guaranteed instruments." A more stable alternative would have been for the government to provide more safe instruments, or for the central bank to provide broader capital safety.

According to Pozsar (p. 25), “Frustrating the financial system's ability to provide these solutions (safe and liquid instruments) while at the same time not addressing the vacuum this creates through policy remain a fundamental source of systemic risk and point to more frequent banking crises ahead."

\section{Rehypothecation}

Hyman Minsky used the term "money manager capitalism" to describe the transition to a financial system based on speculative activities of money managers. The growth of institutional investors like pension funds, sovereign wealth funds, insurance funds, university endowments, and other savings funds run by professional money managers all seeking maximum returns led to many taking on riskier assets in order to gamble for higher returns (Wray 2011). One new way to enhance returns has been to lend idle cash against collateral (repo) or engage in securities lending.

This latest twist to shadow banking activities has added further fragility to the system. During the crisis, the sudden withdrawal of such volatile funding led to rapid deleveraging and "repo runs." With rehypothecation, several additional actors will be affected by the failure of one key institution. The breakdown in market liquidity could then lead to even more requests for central bank interventions.

Singh and Aitken (2010) discuss the recent trend of "rehypothecation" and claim that the size of the shadow banking system, including this activity, is at least 50 percent bigger than documented so far. Rehypothecation occurs when the collateral posted by a prime brokerage client (e.g., a hedge fund) to its prime broker is also used as collateral by the prime broker for its own purposes. The relending of posted collateral is subject to rules (Regulation T) in the US. ${ }^{48}$ Few such rules are in place in the UK, and thus large international banks use London as a base for generating funding based on rehypothecation.

\footnotetext{
${ }^{48}$ Limiting the use to 140 percent of a customer's debit balance.
} 
Pozsar and Singh $(2011$, p. 5) estimated that by the end of 2010 , around $\$ 6$ trillion in off-balance sheet activity could be related to the mining and re-use of source collateral for international banks. Adding this number to the previous estimate for the US shadow banking system yields a total size of the shadow banking sector of around $\$ 18$ trillion. ${ }^{49}$

An important driver for the growth in the repo and rehypothecation market is their special status under US bankruptcy law. In the 2005 revision of the law, derivatives and repo transactions were exempted from the general "temporary stay" provision. Instead, repo agreements can unilaterally enforce the termination provision of the agreement if there is a bankruptcy filing. Without this "safe harbor" protection, a party to a repo contract would be a regular debtor in the bankruptcy proceedings (Gorton and Metric 2010, p. 12). In this way, repo transactions can get ahead of all other creditors in a failing bank.

\section{The Cross-Border Dimension}

A significant part of the borrowing from the Federal Reserve at the peak of the crisis was from European banks that had accumulated substantial dollar-denominated assets prior to the crisis. These positions (many in long-term real estate securities) had been funded by short-term dollar liabilities (much of it from US money market funds). When the crisis hit, their funding position became extremely vulnerable. Borrowing at the modified discount window (TAF) allowed these banks to maintain their position and seek longer-term financing. ${ }^{50}$

In the decade before the crisis, dollar assets such as mortgage-backed securities accounted for half the growth in European banks' foreign exposures over the period between 2000-2007. ${ }^{51}$ Indeed, banks' on-balance sheet dollar exposure in the EU, UK, and Switzerland was estimated to have exceeded $\$ 8$ trillion in 2008.

\footnotetext{
${ }^{49}$ They note that the corrections are large, but the metrics remain poorly understood.

${ }^{50}$ Nicola Cetorelli and Linda S. Goldberg, "Global Banks and Their Internal Capital Markets During the Crisis," Liberty Street Economics (blog), July 11, 2011 http://libertystreeteconomics.newyorkfed.org/2011/07/globalbanks-and-their-internal-capital-markets-during-the-crisis.html

${ }^{51}$ Linda Goldberg and David Skeie, "Why Did U.S. Branches of Foreign Banks Borrow at the Discount Window during the Crisis?" Liberty Street Economics (blog), April 13, 2011 $\mathrm{http} / / /$ libertystreeteconomics.newyorkfed.org/2011/04/why-did-us-branches-of-foreign-banks-borrow-at-thediscount-window-during-the-crisis.html.
} 
Cross-border banking is increasingly important in driving private liquidity around the global economy. A recent report (CGFS 2011) notes that dollar credit to non-US residents reached a record high of 17 percent in 2010 (up from 11 percent in 2000). They also note that US dollar credit to the rest of the world has at times grown faster than credit to US residents. Between 2000 and 2007, dollar credit to non-financial private sector borrowers outside the US grew very rapidly, peaking at 30 percent per annum just before the financial crisis.

To fund this credit expansion, foreign banks had 161 branches and subsidiaries in the US (in 2009) that collectively raised over $\$ 1$ trillion dollars in wholesale funding, of which $\$ 645$ billion was channeled back to their headquarters (Bruno and Shin 2012, p. 3). When the crisis hit, foreign owned US banks were able to access the discount window at the Federal Reserve and channel funds back to their parent banks. In addition, the Federal Reserve initiated a series of dollar swaps with other central banks that enabled them to provide dollar funding to their domestic (foreign) banks. As Cetorelli and Goldberg (2011) conclude: "These dramatic events illustrate the global nature of liquidity management across internationally active financial organizations. Questions for further exploration include how these patterns influence policymaking approaches, lender-of-last-resort activities by central banks, and banking supervision. ${ }^{, 52}$

As Minsky (1985) noted long ago: “The Federal Reserve now acts as lender of last resort to the world dollar-denominated banking system, regardless of where the banks that have the dollar book are domiciled."

\section{How Should Central Banks React?}

This rapid growth of shadow banking and cross-border banking represents a big challenge to central banks, not the least the Federal Reserve. Will they be able to replicate the lender of last resort operations of 2008 if there is a new global liquidity collapse, and should they? Should their balance sheets again be used to prop up dysfunctional markets that have expanded on the basis of a "liquidity illusion"? As Nesvetailova (2008, p. 87) noted in the midst of the GFC:

\footnotetext{
${ }^{52}$ Nicola Cetorelli and Linda S. Goldberg, "Global Banks and Their Internal Capital Markets During the Crisis," Liberty Street Economics (blog), July 11, 2011 http://libertystreeteconomics.newyorkfed.org/2011/07/global-banksand-their-internal-capital-markets-during-the-crisis.html
} 
Originally identified by Keynes, liquidity illusions have been behind many financial euphorias and bubbles throughout history, but it is during the past two decades that illusions of liquidity have become a central element of financial crises around the world. The BIS Committee on the Global Financial System has defined liquidity illusion as a situation in which markets underprice liquidity and financial institutions underestimate liquidity risks (CGFS 2001, p. 2). Essentially, the illusion of liquidity is a false sense of optimism a financial actor (be that company, fund manager or a government) has over the safety and resilience of her portfolio, and/or market as a whole. In periods of economic upturn and optimism, investors eagerly expand their credit lines, often underestimating risks in the belief that their investment structures are safe and liquid. Yet when across the board, financial institutions share optimistic expectations and stretch their portfolios too far, the system as a whole becomes progressively illiquid and therefore, fragile.

\section{Official Liquidity Support}

During the crisis, central banks' balance sheets were used to alleviate strains in the balance sheets of intermediaries. As Adrian and Shin (2009b, p. 46) note: "The spirit of these (liquidity support) policies differed from that of classical monetary policy in that they were explicitly aimed at replacing the collapse of the private sector balance sheet capacity." In fact, they note that under the CPFF in October 2008 the Fed's holding of commercial paper replaced virtually dollar-for-dollar the decline in the outstanding amount of commercial paper. However, they do not question the capacity or willingness of the central bank to engage in this unconventional monetary policy, but just note that "the traditional role of the central bank as lender of last resort has undergone far-reaching innovations" (p. 49).

The recent report on global liquidity by CGFS (2011) notes that improving financial regulations and developing new macro-prudential policy tools will be the first line of defense against further global illiquidity turbulences. The financial reform agenda should help reduce the probability and potential impact of adverse liquidity shocks to the financial system, but they note that disruptions in the supply of private credit cannot be ruled out. They furthermore note that: "This underpins the need for adequate means to provide and distribute official liquidity in a domestic and international context, should a sudden withdrawal of private liquidity threaten financial stability" (CGFS 2011, p. 24). As a result, they suggest that "global liquidity shocks will require interventions by institutions with the ability to supply official liquidity in an elastic 
manner and in potentially very sizeable amounts to break downward liquidity spirals. Only central banks have this ability [italics added]" (Ibid., p. 29).

Pozsar (2011, p. 22) would like central banks to go even further in providing nominal safety to market participants. He notes that institutional investors ("cash pools") prefer to invest cash at a distance from banks, in non-M2 type deposit instruments. The capital safety of such instruments could be improved if central banks would "broaden their lender of last resort function to non-bank intermediaries that issue such instruments, such as broker-dealers (in the case of repos) ... The Federal Reserve's facilities created during the crisis were a step (albeit not a permanent step) in this direction." The extension of the lender of last resort function to a broader "dealer of last resort function" is also supported by Grad et al. (2011) and Mehrling (2011a).

Governor Tarullo (2010) of the Board of Governors of the Federal Reserve responded to the proposals for extending the safety net in a slightly different context ${ }^{53}$ when he noted that it "would require non-trivial changes in bank regulatory policy, as well as the significant extension of discount window access to a new kind of institutions." And he went on to note that the Fed "has traditionally opened the window to non-depository institutions only in particularly stressed conditions." He then suggested that a cost-benefit analysis is surely needed before deciding on such extensions, "with careful specification of the benefits of the repo market, weighed against the likely impact on — among other things — the securitization market and regulatory system."

While the repo and security lending markets surely have benefits for many, and might improve price discovery, efficiency and market liquidity for Treasury, agency, and agency MBS markets, the sheer volume of trading in some of these markets should be questioned. As Pozsar et al. (2010, p. 6) note: "Some segments of the shadow banking system have emerged through various channels of arbitrage with limited economic value."

Gillian Tett of the Financial Times notes that the ability of the shadow banking system to churn collateral and create credit seems impressive on such a small underlying asset base. "But the key question that has hung over the system — and is doubly relevant now — is whether that

\footnotetext{
${ }^{53}$ In response to proposals from Gorton and Metric (2010) to extend the safety net for ABSs.
} 
cloud of trading activity could crumble back into itself? And what might the impact of that be?"54 We might add that the official balance sheets supporting this credit pyramid are quite small and should probably not be totally committed to even further expansion of the shadow banking system.

As Paul Tucker (2010) from the Bank of England notes "there is a need to think through carefully just what really comprises shadow banking and how the regulatory system should treat its different manifestations." The primary task of the "regulation and structure" debate is to make the core banking system safe and sound," i.e., not necessarily support every corner of the unregulated market. If this is so, liquidity support should not be supplied at every instance of market breakdown, and we need to differentiate between situations where market making by the central banks is warranted and situations when it would be unwarranted.

\section{The Official Reform Agenda}

In response to a request from the G20, the Financial Stability Board (FSB) has issued a reportShadow Banking: Strengthening Oversight and Regulation-that (1) seeks to clarify the concept of shadow banking, (2) sets out approaches for effective monitoring of the shadow banking system, and (3) prepares, where necessary, additional regulatory measures to address the systemic risk and regulatory arbitrage concerns posed by the shadow banking system.

The approach taken by FSB relies heavily on information collection and monitoring to enhance understanding of the shadow banking sector and gradually develop a regulatory response. The report proposed five work streams to assess the case for further regulatory action in detail:

1) The regulation of banks' interactions with shadow banking entities ${ }^{55}$

2) The regulatory reform of money market funds $(\mathrm{MMFs})^{56}$

3) The regulation of other shadow banking entities

\footnotetext{
${ }^{54}$ Gillian Tett, "Web of shadow banking must be unraveled," Financial Times, August 12, 2010 http://www.ft.com/intl/cms/s/0/112ff210-a62b-11df-9cb9-00144feabdc0.html\#axzz1qbbtd356.

${ }_{55}^{55}$ The Basel Committee will deliver a report to the FSB by July 2012 with proposed policy recommendations.

${ }^{56}$ The SEC has noticed that there will be proposals coming out soon for US MMFs that will suggest either a capital buffer option to serve as a cushion for money market funds in times of emergency or floating NAVs, which would eliminate the expectation of stability that accompanies the $\$ 1$ stable NAV.
} 
4) The regulation of securitization

5) The regulation of securities lending and repos ${ }^{57}$

All these initiatives will report to the FSB during 2012.

While all these initiatives are welcome, one can be somewhat skeptical about what can be achieved through "intensive monitoring and possible regulatory measures." It is enough to recall the previous Basel Committee report from 2001 on the same topic (Review of issues relating to Highly Leveraged Institutions - HLIs), which concluded that everything was fine:

The HLIWG is encouraged by firms' continued progress in implementing the HLI Sound Practice recommendations made by the Basel Committee and IOSCO. Senior managements have strengthened their oversight of HLI activities through improved policies and a clearer definition of overall risk appetites.

In addition, there are many who question the core premise of the Basel capital and liquidity framework, especially the risk weight system and the theoretical models underpinning the system. Paul Atkinson and Adrian Blundell-Wignall of the Organization for Economic Cooperation and Development (OECD) recently suggested that the Basel framework is "opaque and far too complex" and does not take sufficient account of the enormous growth and importance of derivatives and collateral transactions among international active banks. They suggest that

the risk weight system at the core of the approach for calculating capital charges needs to be scrapped in its entirety and a more coherent approach to exposures arising from derivatives, notionally in excess of $\$ 600$ trillion at the end of 2010 , must be found. ${ }^{58}$

\section{Minsky's Twin Approach}

Hyman Minsky provides an alternative policy prescription that recognizes the need for a strong lender of last resort function by central banks in a crisis, but only if it is accompanied by strong regulatory measures to ensure that the follies of the past will not so soon be repeated. In addition, he considers deficit-financed government spending to be an essential supplement to

\footnotetext{
${ }^{57}$ This work stream will review possible macro prudential measures related to margins and haircuts.

${ }^{58}$ Paul Atkinson and Adrian Blundell-Wignall, "Basel Regulation Needs to be Rethought in the Age of Derivatives," VOX (blog), February 28, 2012 http://www.voxeu.org/index.php?q=node/7672.
} 
compensate for the withdrawal of private demand as households and firms attempt to restore their balance sheets.

\section{The Lender of Last Resort Policy}

"Financial crises take place because economic units need or desire more cash than is available from their usual sources and so they resort to unusual ways to raise cash" (Minsky 1982, p. 125). When economic actors start liquidating assets to restore cash flow positions, central bank intervention may be required. "Even in the face of a widespread need or desire to acquire cash by selling assets, not all assets are allowed to fall in price. The price of some assets is stabilized by central bank purchases or loans (refinancing positions); such assets can be called protected" (Ibid., p. 128). At this point, the central bank must "assure that the supply of funds in key position-making markets is not disrupted by a run, and it must clearly define the financial markets it will protect" (Ibid., p. 359).

During a boom, the margin of safety decreases and economic units take on more and more leverage. Increasing interest rates gradually reduce the net present value of future income streams, making the levered positions look vulnerable. Sectoral difficulties can then escalate into a general financial panic. Money markets also have a tendency to expand during boom periods, providing elastic private credit. As money markets expand, a general decline in the liquidity of households and firms follows. This makes them vulnerable to a fall in asset values. There will be a general expectation about liquidity in key asset markets that cannot be sustained unless the central bank moves in and supports the price, i.e., monetization by the central bank. In Minsky's view, it was important for the central bank to acknowledge this responsibility and act in a timely fashion to prevent a slide into another depression.

The timing of lender of last resort intervention can be challenging, though. Minsky (1982, p. 153) noted that: "Perhaps the optimal way to handle a euphoric economy is to allow a crisis to develop - so that the portfolios acceptable under euphoric conditions are found to be dangerous - but to act before any severe losses in market values, such as are associated with an actual crisis, take place."

If monetary conditions are eased too soon, then no substantial unlayering of balance sheets will be induced, and the total effect of monetary actions might 
very well be to reinforce the euphoric expansion. If the lender-of-last-resort functions are exercised too late and too little, then the decline in asset prices will lead to a stagnation of investment and a deeper and more protracted recession.

Given that the error of easing too soon only delays the problem of constraining a euphoric situation, it may be that the best choice for monetary policy really involves preventing those more severe losses in asset prices that lead to deep depressions, rather than preventing any disorderly or near-crisis conditions.

If capitalism reacts to past success by trying to explode, it may be that the only effective way to stabilize the system, short of direct investment controls, is to allow minor financial crisis to occur from time to time. (Ibid.)

\section{Dealer of Last Resort}

Minsky (1982, p. 76) noted that financial market and banking innovations had changed the nature of the financial system over the past decades. Beginning with the emergence of the federal funds market in the mid-1950s, changes such as certificates of deposits, the explosive growth of commercial paper, the rise and fall of real estate investment trusts (REITs), ${ }^{59}$ the internationalization of banking, and the wide use of repurchase agreements have occurred.

"Each time the Federal Reserve acts as a lender of last resort, it prevents some financial institution or some financial market from collapsing. When it does this, it introduces additional Federal Reserve liabilities into the economy and extends a Federal Reserve guarantee over some set of financial practices. Thus, in 1966 it protected banks that used certificates of deposits, in 1969-70 it protected the commercial paper market, and in 1974-75 it extended the Federal Reserve guarantee to those who owned the liabilities of offshore branches of American banks. By legitimizing financial market practices through its implicit endorsement, the Federal Reserve in 1966, 1969-70, and 1974-75 set the stage for the financing of subsequent inflationary burst" (Ibid., p. 194).

He observed that some would limit the central bank's money-market responsibilities to the maintenance of the liquidity of the banking system and of orderly conditions in the government bond market (Ibid., p. 174). With much of the financing taking place outside the banking sector, even in his time, this was too narrow a view according to Minsky. He notes that "we now have a two-tier monetary system," where one part is protected by the central bank and

${ }^{59}$ Real Estate Investment Trusts 
deposit insurance while the other (money-market) system lacks any formal support. "If there is no provision for supplying the desired money to the institutions which have the undesired money as liabilities, a run can have disastrous consequences. As financial markets replicate our experience of 1966, 1969-1970, and 1974-1975 and drive toward the brink of a financial crisis, some lender of last resort intervention, because of the money market funds, is likely to be needed" (Ibid., p. 76).

"What is required to counteract the effects of such evolutionary developments is a broadened view of central bank responsibilities and a clear recognition that, in spite of corrective steps, the money market will always stretch liquidity to the breaking point during a boom" (Ibid., p. 175). Minsky then contrasts the narrow lender of last resort policy of the Federal Reserve with the classical Bank of England position of lender of last resort to the discount houses, which in terms of paper, penetrated deeply into the British money market. As new institutions and markets emerged, they would indirectly be supported by the central bank in such a setup. "Hence the central bank would prevent the widespread loss of liquidity resulting from a crisis in one segment of the market" (Ibid.)

The discount window should be open to selected money market position takers (dealers) and the Federal Reserve should move toward furnishing a large portion of the total reserves of banks by discounting operations. His policy advice followed from an awareness of the possibility of a financial crisis and of the need to have broad, deep, and resilient markets for a wide spectrum of financial instruments once a financial crisis threatens, so that the effects of the crisis could be moderated. (Ibid., p. 120)

However, the central bank's promise to intervene to maintain orderly conditions in some markets will only be credible if the central bank is already operating in that market (Ibid., p. 154). According to Minsky, it follows that the central bank should be a supplier of funds to the particular secondary market it desires to support. The Federal Reserve should therefore abandon its "Treasuries only" policy and regularly "deal" and "discount" in a wide variety of asset markets (Ibid.). 


\section{The Eurodollar Market}

As noted by the CGFS (2011) report on global finance, the growth in dollar lending to non-US residents has been very strong recently and continues to grow rapidly. Minsky noted already in 1985 that "the Federal Reserve is the de facto lender of last resort to the international financial (dollar) structure" (Minsky 1985, p. 15). Since foreign lenders of dollars get their dollars in New York, either directly with correspondent banks or through their central banks (who get dollars through swap facilities with the Fed), it is the actions of the Federal Reserve that determine the availability of dollars in general, and also for foreign owned banks. Thus Minsky concludes that, "the Federal Reserve now acts as lender of last resort to the world dollar denominated banking system, regardless of where the banks that have the dollar book are domiciled" (Ibid.) He notes that the Federal Reserve acknowledged this role when it provided liquidity support to Franklin National bank when it suffered a run on its overseas branch in London in 1974, and ten years later as it supported Continental Illinois when withdrawals of offshore deposits triggered its collapse (Ibid., p. 16). ${ }^{60}$

He argues, however, that this responsibility is problematic because the Federal Reserve "has responsibilities where it does not have control, responsibilities which depend on accepting the importance of maintaining the offshore dollar-denominated banking system" (Ibid.). This system is still growing overseas outside the control of the Federal Reserve, and also in part outside the control of any other regulators (ref. rehypothecation in London).

Minsky also explains that this dollar-denominated banking system leads to a demand for dollar assets - including Treasuries - that is related to the growth and currency denomination of the international offshore banking system, and not the needs of the US economy: "In good part, the US financial structure depends on the continued use of the dollar as the international currency of denomination" (Ibid.).

The Fed has so far provided an elastic supply of dollars during the crisis, but increasing concern in Congress has led it to discontinue direct dollar lending to foreign-owned banks in the US and instead offer dollar swap-lines to other central banks. There is, however, a potential tension here between the huge demand from the dollar-based international banking system for

\footnotetext{
${ }^{60}$ See also Schwartz (1992, p. 64).
} 
official dollar liquidity in a crisis, and the political will and ability of the Federal Reserve to "supply official liquidity in an elastic manner and in potentially very sizeable amounts" (CGFS 2011). As the international dollar-based banking system increases, this is going to become an even bigger problem in the future. ${ }^{61}$

\section{Strong Regulatory Response Needed}

Minsky noted that there is always a problematic aspect to central banks' lender of last resort interventions, as they tend to validate the past use of an instrument and extend an implicit guarantee of its future value: "Unless the regulatory apparatus is extended to control, constrain, and perhaps even forbid the financing practices that caused the need for lender-of-last-resort activity, the success enjoyed by these interventions in preventing a deep depression will be transitory; with a lag, another situation requiring intervention will occur" (Minsky 1986, p. 59).

Minsky (1985, p. 17) also noted that there is a distinct risk that central bank lender of last resort intervention will lead banks to engage in risky behavior: "There is a 'moral hazard' problem with regard to the protected multibillion dollar banks that does not exist for smaller banks .... These banks can bias their asset and liability innovations towards instruments that can compromise their liquidity and equity and still expect to be protected."

As long as the Federal Reserve fears disasters, the odds are with the giant institutions forcing the Federal Reserve to intervene to support their operations and refinance them whenever a crisis threatens. The Federal Reserve must not be afraid of calling the bluff of any institution, of allowing it to fail and to wipe out not only its shareholders' equity but some of the depositors value as well. (Ibid.)

Since the fallout from the failure of a large bank could be considerable and could prevent the Fed from calling their "bluff," Minsky suggests that the largest banks should be broken up so that the Federal Reserve can always stand aside and let any bank fail. This implies that there should ideally be a maximum size to a bank, for example $\$ 10$ billion. But he acknowledges that it may be utopian to expect a reform of the banking structure along these lines, and consequently

\footnotetext{
${ }^{61}$ Discussions have been going on for years about who is responsible for these mega-big international banks in a crisis. Despite some recent initiatives (e.g., on living wills, etc.) progress has been slow so far, and the banks have every incentive to keep the lines of responsibilities blurred to maximize their chances of being bailed out in a new crisis.
} 
"we can expect intervention by the Federal Reserve to continue to take place whenever any of these giant banks are in trouble" (Ibid., p. 18). ${ }^{62}$

Still, central banks have to prevail in finding other ways to constrain speculative activities among banks. "It is virtually assured that there will be another crisis in the near future unless, of course, the central bank outlaws the fragility inducing financial practices" (Minsky 1986, p. 364).

According to Minsky, central bank lender of last resort interventions must be accompanied by policies that favor hedge-financing: "The more the Federal Reserve can tilt banking toward financing trade and production inventories with short time spans, the more stable the financial system and the smaller the special refinancing needed to prevent another full-blown crisis" (Ibid., p. 364-5). Institutional reforms that constrain corporate external finance and the capabilities of banks and other financial institutions to support explosive situations may be needed (Ibid., p. 59).

"The maintenance of a robust financial structure is a precondition for effective antiinflation and full employment policies without a need to hazard deep depressions. This implies that policies to control and guide the evolution of finance are necessary" (Minsky 1982, p. 92). "In order to do better, we have to establish and enforce a 'good financial society' in which the tendency by business and bankers to engage in speculative finance is constrained" (Minsky 1977, p. 26).

Minsky had an intimate knowledge of banking and financial markets. This led him to detect fragile financing practices and develop these observations into a coherent theory that is refreshingly modern. He discussed the too big to fail issue and its challenges for central banks immediately after the Continental Illinois rescue in 1984. And he described the tendency of markets to innovate and create private liquidity in booms, but also their vulnerabilities to runs once expectations about the future change. At this point, central bank intervention is needed to prevent a contagious situation. Minsky clearly favored a broad mandate for central bank liquidity support in such crises to prevent market-wide failures. However, he was still cognizant of the hazards of such unlimited support and advocated (although somewhat inconsistently) a

\footnotetext{
${ }^{62}$ See Johnson and Kwak (2010) for a thorough analysis of TBTF banks.
} 
strong regulatory response to limit new speculative practices in the wake of a lender of last resort intervention.

\section{EXCESSIVE GLOBAL CREDIT}

\section{In Search of a Better Theoretical Paradigm of Money and Banking}

There is a growing concern among policymakers that central banks' capacity to provide unlimited liquidity support in a future crisis may be stretched too far by the exponential growth in financial markets. Hervé Hannoun (2012) of the Bank for International Settlements talks about "the illusion of unlimited intervention" and warns about the consequences of using either "the printing press" or "a bazooka" to calm markets. Adair Turner from the UK's FSA suggests that market growth is not always good and that "not all financial activity is axiomatically useful" (Turner 2011, p. 25). Paul Tucker (2012, p. 12) from the Bank of England admits that "we need to be ready to contain private sector liquidity creation," while Borio and Disyatat (2011) from the BIS add that to reduce the likelihood and severity of financial crises, "the main policy issue is how to address the 'excess elasticity' of the (international financial) system."

This new awareness about the dangers of excessive credit creation comes together with an increased recognition that the theoretical paradigm underpinning much of regulatory agenda up to the GFC needs to be revised, or at least updated. ${ }^{63}$ For too long, policies have been designed based on models without banks, finance, or credit. Borio and Disyatat (2011, p. 31) point out that

in the canonical New Keynesian paradigm, rather paradoxically, money and credit are entirely redundant or at least inessential. It is an economy in which credit is just a vague shadow in the background: since credit does not affect behavior, its evolution does not need to be tracked. The underlying economy is, in this sense, a real economy disguised as a monetary one. By doing away with the quantities of credit and deposits it has obscured the factors that are at the very core of financial instability.

Friedman (2012, p. 302) observes that "in retrospect, the economics profession's focus on money-meaning various subsets of instruments on the liability side of the banking system's

\footnotetext{
${ }^{63}$ See Brookings (2011): Rethinking Central Banking.
} 
balance sheet in contrast to bank assets, and correspondingly the deposit assets on the public's balance sheet in contrast to the liabilities that the public issues - turns out to have been a halfcentury-long diversion that did not serve our profession well."

These views are certainly not new. J. M. Keynes (1936) criticized neo-classical theory for using real economy models to analyze issues facing a monetary economy. Minsky (1982, $\mathrm{p}$. 91) observed that "the logical flaw in standard economic theory is that it is unable to assimilate capital assets and money of the kind we have, which is created by banks as they finance capital asset production and ownership." This "deficiency" of standard theory has also been acknowledged by mainstream economists, like Frank Hahn's famous admission (in 1984, p. 1): "The most serious challenge that the existence of money poses to the (standard) theory is this: the best-developed model of the economy cannot find room for it." And Goodhart and Tsomocos (2011, p. 3) add that in the standard models "everyone is risk-less, so anyone's IOU can and would be immediately and fully acceptable in payment for goods or services." There is no need for money!

Unfortunately, this challenge to standard theory was not heeded by economists before the GFC, as they generally moved in the direction of even more abstract and stylized models, where coordination failures and instability were simply assumed away. As Leijonhufvud (1997) noticed: "The macroeconomic generalization of Modigliani-Miller implies among other things Ricardian Equivalence, the Ineffectiveness of Open Market Operations and more generally the irrelevance of inside money and credit." No wonder that former Fed Chairman Greenspan admitted "shocked disbelief" while watching his "whole intellectual edifice collapse in the summer of 2007" and that he confessed that he had "put too much faith in the self-correcting power of free markets." ${ }^{\prime \prime 4}$ And he added that "the immense and largely unregulated business of spreading financial risk widely, through the use of exotic financial instruments called derivatives, had gotten out of control and had added to the havoc of the crisis."

Chairman Adair Turner (2011, p. 27) reflects on this intellectual hubris in his 2011 Clare Lecture: Reforming Finance: Are We Being Radical Enough? He observes that it was "striking in the pre-crisis years how dominant and how overconfident, at least in the arena of financial

\footnotetext{
${ }^{64}$ Quoted in Bezemer (2011, p. 6) and NY Times, October 23, 2008
} 
economics, was a simplified version of equilibrium theory which saw market completion as the cure to all problems, and mathematical sophistication decoupled from philosophical understanding as the key to effective risk management."

Fatal policy mistakes were thus based on overconfidence in the tendency of financial markets towards rational and efficient equilibria. And that overconfidence had, in the years before the crisis, become a belief system. In regulators such as the FSA, the assumption that financial innovation and market liquidity were valuable because they completed markets and price discovery, was not just accepted, it was part of the institutional DNA. (Turner 2011, p. 29)

He also notes that during the years of the "Great Moderation," a dominant, over-simplified, and dangerous conventional wisdom developed as the simplified models of academia were translated into public policy. The International Monetary Fund has also acknowledged this tendency toward "group-think" in a recent internal evaluation report on the GFC. Their panel of outside experts noted that (IEO/IMF 2011, Background Papers I, p. 2):

- The Fund had made insufficient progress in taking into account the interactions between the financial and real sectors and the role of credit in its analysis. Fund economists had become over-dependent on a narrow group of economic models.

- For some time, many outside the Fund and some inside the Fund had raised major concerns about financial stability, but these concerns were not sufficiently listened to.

- Part of the problem was the similar mindset of many mainstream economists working at the Fund with similar background and training who were not open to dissenting views. Both in and outside the Fund there were other economists and policymakers with contrarian views. But their views were not encouraged or closely examined within the Fund.

Fortunately, there is a rich theoretical tradition dealing with the instability of financial markets that can be tapped to improve our understanding of modern capitalist economies with banks, finance, and credit. ${ }^{65}$ One major contributor in this vein is Minsky, who built his

\footnotetext{
${ }^{65}$ See Bezemer, 2009 for a nice overview of "those that saw the crisis coming."
} 
financial instability theory on the back of J. M. Keynes' deep insights into the working of a modern monetary economy. According to Martin Wolf of the Financial Times, "His masterpiece Stabilizing an Unstable Economy, provides incomparably the best account of why this theory is wrong," i.e., that the modern capitalist economy is inherently stable:

Periods of stability and prosperity sow the seeds of their downfall. The leveraging of returns, principally by borrowing, is then viewed as a certain route to wealth. Those engaged in the financial system create - and profit greatly from - such leverage. When people underestimate perils, as they do in good times, leverage explodes. ${ }^{66}$

Understanding the leverage cycle was central to Minsky's work. Since "the financing of investment and capital assets within a modern banking environment makes the effective money supply endogenous ... there is a great deal of deviation amplifying complementarity among markets" (Minsky 1982, p. 91).

Understanding such deviating market behavior, especially in the short-term money markets and foreign exchange markets, should be a key preoccupation of academics and policymakers (Shirakawa 2010, p. 9). This may require some novel approaches as mainstream theory needs to interact with and build on insights from non-traditional schools of thought. As Borio and Disyatat (2011, p. 31) note, a deeper understanding of financial crises and the workings of our modern finance-based global economy will require "a rediscovery of the essence of monetary analysis."

\section{The Instability of Private Credit}

The GFC revealed the instability of financial markets and the very strong procyclical forces of private credit. According to Minsky, this instability of private credit is inherent in a capitalist market economy where investment and capital assets are financed by private banks. Before reviewing Minsky's financial instability hypothesis, it is instructive to take a brief look at some recent reports that have "re-discovered" this instability of credit and the endogenous instability of the financial system.

\footnotetext{
${ }^{66}$ Martin Wolf, “The world's hunger for public goods," Financial Times, January 24, 2012.
} 


\section{Liquidity Cycles}

The recent CGFS report (2011) on global liquidity shows that global liquidity moves in tandem with various proxies for risk appetite. International bank credit exhibits strong boom-bust cycles that appear to correspond closely to episodes of financial distress, whereas periods of particularly strong growth in cross-border credit are often characterized by elevated risk appetite. As Tucker (2011, p. 3) notes,

During good times, everyone feels that they are achieving a nice balance of risk and return. They are getting, they think, safety, liquidity and return! But something eventually happens to cause them to wake up, and to see the risks they have neglected.

Coeuré (2012) from the ECB admits that "the self-reinforcing interaction between risk appetite and liquidity is not yet sufficiently appreciated," but it is this "particular interaction that ultimately determines the relationship between the official and the overall level of global liquidity." Official liquidity is funding provided by the public sector ("outside money"), whereas private liquidity ("inside money") is endogenous to the conditions in the global financial system (Domanski et al. 2011, p. 59). It depends on the willingness of market participants to supply funding or trade in securities markets:

Private liquidity is to a large degree created through cross-border operations of banks and other financial institutions, and increasingly within the shadow banking system. In normal times, private liquidity dominates official liquidity. But private liquidity is highly procyclical and highly endogenous to the conditions that prevail in the global financial system. The inherent endogeneity of private liquidity means that it can easily evaporate in times of financial stress [italics added]. (Coeuré 2012)

As Borio and Disyatat (2011) have already observed, it requires a leap of imagination to think of liquidity as something that can evaporate. Standard theory has traditionally modeled banks as intermediaries between savers and investors. Banks receive a tangible "good" savings - and pass it on to the investor. Nothing is lost in the process. The alternative, and more realistic, view of banking recognizes that "banks can create money out of nothing. ${ }^{, 67}$ It then

\footnotetext{
${ }^{67}$ Martin Wolf, "The Fed is right to turn on the tap," Financial Times, November 9, 2010.
} 
follows logically that this private money creation can disappear. As Adrian and Shin (2009a, p. 10) also remark:

The fluctuations of credit in the context of secured lending expose the fallacy of the "lump of liquidity" in the financial system. The language of "liquidity" suggests a stock of available funding in the financial system which is redistributed as needed. However, when liquidity dries up, it disappears altogether rather than being re-allocated elsewhere.

Domanski et al. (2011, p. 59, 67) add that the distinction between liquidity created by private and public sector market participants is key to understanding the sources of global liquidity and its dynamics, but admits that "the interaction of private and public liquidity is not fully understood." An important clue to our improved understanding could be the distinction between "inside" and "outside" money, two concepts developed by the American economists Gurley and Shaw in the 1950s, but since largely forgotten. ${ }^{68}$

Friedman (2012, p. 302) supports the drive to incorporate inside liabilities within our models, but he also argues that we then have to "abandon one of the conventional shortcuts that we so often use in macroeconomic analysis: namely, the representative agent construct. If all agents were identical, there would of course be no reason for any one of them to borrow from, or lend to, another."

\section{Instability of "Near-Monies"}

That private money is not cash and that all IOUs are not equal should not come as a surprise. If we look more closely at earlier crises, we will find that the collapse of the shadow banking system during the recent GFC is not unprecedented. Henry Thornton made the same observations in his 1802 book, An Enquiry into the Nature and Effects of the Paper Credit of Great Britain:

When confidence rises to a certain height in a country, it occurs to some persons, that profit may be obtained by issuing notes, which purport to be exchangeable for money; and which, through the known facility of thus exchanging them, may circulate in its stead. (Thornton 1802, Chapter III, p. 37)

\footnotetext{
${ }^{68}$ See Gurley and Shaw (1960) and Mehrling (1998), Chapter III for a review of Edward Shaw's work. 
And as Buiter (2008, p. 523) observes "the liquidity of markets is rarely a deep, structural characteristic, but the endogenous outcome of the interaction of many partially and poorly informed would-be buyers and sellers. Market liquidity can vanish at short notice, just like funding liquidity." Gorton and Metric (2010, p. 12) add: "liquidity requires symmetric information, which is easiest to achieve when everyone is ignorant."

That the "moneyness" of financial claims can vary and even disappear was well known to the classical economists. As a result of the GFC, these insights have now been rediscovered; the concepts of "fair-weather" and "foul-weather" liquidity are indeed nothing new:

Claims may possess what has been entitled "fair-weather" liquidity, and debts may possess what might be termed "foul-weather" illiquidity. During good times, when there is no mass attempt to call claims, they are extremely liquid and function as good money substitutes; debts, on the other hand, which can be renewed or refinanced easily, are not very illiquid, and little cash reserve is needed to meet obligations. When critical times arrive, however, and general liquidation is attempted, creditors doubt the moneyness of their claims, and debtors encounter increased pressure to pay and greater obstacles to refinancing. Hence claims lose their ability to substitute for cash, and debts acquire the capacity to require the accumulation of cash balances. This foul-weather illiquidity of debts is about what A. G. Hart once entitled the "mythology of maturities." During prosperous times, debts have no effective maturity, because they can easily be refinanced. During bad times the maturity of obligations is very real and, in many cases, accelerated. (McKean, 1948, p. 515)

\section{Understanding Endogenous Finance}

The GFC was a wake-up call for many. For some, the crisis was a one-time occurrence, an extreme "tail-event" that could not have been predicted. For others (in the Minsky tradition), the crisis was an expected event that followed after a long period of deregulation and lax financial supervision. For them, instability is endogenous to the financial system and there is no need for an external shock to unleash the destructive forces of fire sales and deleveraging. As Minsky (1982, p. 123) noted: "A euphoric new era [read: the Great Moderation] means that an investment boom is combined with pervasive liquidity-decreasing portfolio transformations." This can go on for some time, until finally reality kicks in and expectations of future cash flows 
are revised downward. Unless the central bank intervenes to stem the cumulative forces of asset sales and liquidity destruction, this can then result in a severe depression.

Key to understanding this endogenous cyclical nature of our capitalist economies is the role of banks and their behavior. And as noted above, in order for us to understand banks and finance better, we need to revise some fundamental concepts of both the economy and our economic models.

\section{The Procyclical Nature of Banking}

The procyclical nature of bank credit and the interaction with the shadow banking system has been studied intensively since the GFC. The seminal paper on the shadow banking system by Pozsar et al. (2010) from the Federal Reserve Bank of New York has been followed by a range of in-depth studies on shadow banking, the repurchase market and securities lending. ${ }^{69}$ Through this work, we have gained a better understanding of "the repo machine" that was at the center of the financial crisis in the US.

Adrian and Shin (2009b) explore the hypothesis that "the financial intermediary sector, far from being passive, is instead the engine that drives the boom-bust cycle [italics added]." Rather than looking at how financial frictions will affect the real economy, they go straight to the financial sector and try to understand how finance became the propagator of the crisis instead of a conduit for prosperity. They note (2009a, p. 11) that securitization was intended to disperse risks associated with bank lending so that investors who were better able to absorb losses would share the risks.

But in reality, securitization worked to concentrate risks in the banking sector. There was a simple reason for this. Banks and other intermediaries wanted to increase their leverage - to become more indebted - so as to spice up their shortterm profit. So, rather than dispersing risks evenly throughout the economy, banks and other intermediaries bought each other's securities with borrowed money. As a result, far from dispersing risks, securitization had the perverse effect of concentrating all the risks in the banking system itself.

\footnotetext{
${ }^{69}$ See several working papers by Adrian and Shin, and also the IMF working papers by Pozsar and Singh on rehypothecation .
} 
That securitization was risk-reducing and conducive to stability was a widely held view before the GFC. Most policymakers were supportive of, and even encouraged, the attempts by banks to shrink their balance sheets, as this would enable end investors to allocate resources more efficiently - at least that was what the theory claimed. As the IMF noted in its Global Financial Stability Report in 2005, "Overall, there has been a transfer of financial risk over a number of years, away from the banking sector to nonbanking sectors, be they financial or the household sector. This dispersion of risk has made the financial system more resilient, not the least because the household sector is acting more as a 'shock absorber of last resort' [italics added]" (IMF 2005).

\section{Bank Management Motivation}

After the GFC, it was obvious that bank compensation policies had been a contributing factor to the speculative activities in many large financial institutions. The Financial Stability Board noted in a 2009 report that

high short-term profits led to generous bonus payments to employees without adequate regard to the longer-term risks they imposed on their firms. These perverse incentives amplified the excessive risk-taking that severely threatened the global financial system and left firms with fewer resources to absorb losses as risks materialised. The lack of attention to risk also contributed to the large, in some cases extreme absolute levels of compensation in the industry. (FSB 2009, p. 1)

This observation led them to adopt new Principles for Sound Compensation Practices that are "intended to reduce incentives towards excessive risk taking that may arise from the structure of compensation schemes." However, this tendency toward excessive risk taking should not have come as a surprise to those who had read Chapter 10 of Hyman Minsky's book Stabilizing an Unstable Economy. His insights into the motivation of bank managers are so perceptive they are worth citing at length:

The typical professional bank president is not a rich man when he starts his career. As a bank president he is a hired hand trying to achieve a personal fortune. But given the tax structure, it is difficult to accumulate a fortune by saving out of income; the most efficient route for a business executive is by way of stock options and the capital gains that accrue as the stock market price per 
share rises. As holders of stock options, bank management is interested in the price, on the exchanges, of their bank's shares.

The price of any stock is related to the earnings per share, the capitalization rate on earnings of the bank's perceived risk class, and the expected rate of growth of such earnings. If bank management can accelerate the growth rate of earnings by increasing leverage without a decrease in the perceived security and safety of the bank's earnings, then the price of shares will rise because both earnings and the capitalization rate on earnings that reflects growth expectations rise. In a capitalist society with institutionalized organizations and tax laws such as ours, fortune-seeking by the mangers of institutionalized enterprises leads to an emphasis upon growth, which in turn leads to efforts to increase leverage. But increased leverage by banks and ordinary firms decreases the margins of safety and thus increases the potential for instability of the economy. (Minsky 1986, p. 266)

Minsky concluded that to "control the disruptive influence that emanates from banking, it is necessary to set limits upon permissible leverage ratios and to constrain the growth of bank equity to a rate that is compatible with noninflationary economic growth," but he admitted that this was "a principle that is much easier to state than to translate into practice" (Ibid., p. 272). As the GFC showed us, this is spot-on.

\section{Banks Create Credit}

Recognizing that banks are not primarily "intermediaries," but more often "creators of private sector liquidity [italics added]" was a key motivating factor behind the New Deal banking legislation in the mid-30s (Tucker 2012, p. 12). The type of behavior that Minsky later described so accurately was exposed before Congress in hearings lead by Ferdinand Pecora in $1933 .{ }^{70}$ He revealed how the large Wall Street banks were guilty of shocking financial abuses, from selling worthless bonds to manipulating their own stock prices. Most offensive of all was the excessive compensation and bonuses awarded to executives for peddling shoddy securities to the American public. These revelations paved the way for the Glass-Steagall legislation that separated speculative investment banking from the more mundane commercial banking.

Realizing that the essence of our contemporary monetary system is the creation of money, "out of thin air," by private banks' often foolish lending leads necessarily to a different

\footnotetext{
${ }^{70}$ Read Perino (2010) for a thrilling account of the hearings that forever changed American finance.
} 
perspective on the need for banking regulation. And since the money supply is simply the liability counterpart of private credit decisions, instability is baked into the economic cake. ${ }^{71}$

Or, as the Bank of England notes in an article about the factors affecting the money supply, "By far the largest role in creating broad money is played by the banking sector ... when banks make loans they create additional deposits for those that have been borrowed the money" (Berry 2007). In Paul Tucker's words: “As long as banks are perceived as sound, they can extend credit by simply increasing the customers' current account, i.e., banks extend credit by creating money" (quoted in Dyson et al. 2011, p. 31).

Minsky also observed that the nominal money supply in our fractional reserve banking system can be almost infinitely elastic (Minsky 1982, p. 132), and he added that the increased use of securitization "implies that there is no limit to bank initiative in creating credits for there is no recourse to bank capital, and because the credits do not absorb high-powered money (bank reserves)" (Minsky 2008, p. 3).

Bank credit is essential for productive investment and economic growth, but bank credit can also be immensely destructive. As Minsky observed: "We should expect the private, profitmaximizing, risk-averting commercial banks to behave perversely, in that with a decrease in uncertainty they are willing and eager to increase the money supply and with an increase in uncertainty they act to contract the money supply" (Minsky 1982, p. 132). This procyclical behavior was exposed in full during and after the latest financial crisis.

\section{Minsky's Fragility Hypothesis}

Minsky's financial instability hypothesis (FIH) is an attempt to build a theory that is more relevant to our financially sophisticated capitalist economy and to show why such an economy is unstable (Minsky 1982, p. 69). Such a theory is required if we are to understand the recurrent financial crises affecting our economies. Instability should be part of the theory (an endogenous phenomenon) and not simply the result of some arbitrary external shocks. Our economy is not unstable because it is shocked by oil, wars, or monetary surprises, but because of its nature. As

\footnotetext{
${ }^{71}$ Martin Wolf was a member of the Independent Banking Commission in the UK that recommended that the retail business of banks should be "ring-fenced" to avoid contagion from proprietary trading. See Martin Wolf, "The Fed is right to turn on the tap," Financial Times, November 9, 2010 and "The world's hunger for public goods,"

Financial Times, January 24, 2012.
} 
Minsky noted: "It is self-evident that if a theory is to explain an event, the event must be possible within the theory" (Minsky 1982, p. 16).

But, neoclassical theory treats the complex system of financial institutions and instruments that are used to finance ownership of capital assets in a cavalier way. (In fact) a detailed analysis of the behavior of financial institutions and the way the interrelations between financial units and operating units affect the performance of the economy is absent from the core of standard theory. (Minsky 1982, p. 17)

Understanding the behavior of financial institutions and the way they provide financing for investment and positions in capital assets are essential (Minsky 1982, p. 17).

An economy with private debt is especially vulnerable to changes in the pace of investment, for investment determines both aggregate demand and the viability of debt structures. The instability that such an economy exhibits follows from the subjective nature of expectations about the future course of investment, as well as the subjective determination by bankers and their business clients of the appropriate liability structure for the financing capital assets.

Acceptable liability structures are based upon some margin of safety so that expected cash flows, even in periods when the economy is not doing so well, will cover contractual debt payments. As the period over which the economy does well lengthens, two things become evident in the board rooms. Existing debt are easily validated and units that were heavily in debt prospered; it paid to lever. After the event it becomes apparent that the margins of safety built into debt structures were too great. As a result, over a period in which the economy does well, views about acceptable debt structures changes.

The resulting increase in the weight of debt financing raises the price of capital assets and increases investment. As this continues the economy is transformed into a boom economy.

... Stable growth is (thus) inconsistent with the manner in which investment is determined in an economy in which debt-financed ownership of capital assets exists. It follows that the fundamental instability of a capitalist economy is upward. This tendency to transform doing well into a speculative investment boom is the basic instability in a capitalist economy (Minsky 1982, p. 66).

Innovations and new financial instruments increase the amount of financing when things go well. Increased availability of finance bids up asset prices, which provides improved collateral values for even more credit and investment (Geanakoplos 2010). In this way, finance 
becomes endogenously determined. Instability is determined by mechanisms within the system, not outside of it. As Tucker (2011, p. 2) observes:

It is worth reminding ourselves of the Rational Expectation paradigm, which has dominated macroeconomics and finance since the '70s. It posits a state of affairs in which agents know the world - know the structure of the model, and so have model-consistent expectations. Bad things can happen-but only in virtue of exogenous shocks. And depending on the structure of the world, those bad states can be relatively small beer, as famously argued by Lucas on the relative unimportance of business cycles.

Minsky noted that the real world, with uncertainty and instability, looks quite differently. We are then confronted with some real policy challenges that do not appear in the stylized RE models:

The current institutional structure offers us unappetizing alternatives; we need to alter it, recognizing that the essential critical flaw in capitalism is instability, and that instability is due to the way capital asset holding and accumulation are financed. Simons was correct: Banking, that is, the financing of capital asset ownership and investment, is a critical destabilizing phenomenon. But as Simons realized, control of banking - money, if you wish — is not enough; the liability structures available to units that owe the massive capital assets of the economy must also be constrained.

The fundamental dilemma in economic organization is how to preserve the vitality and resilience of decentralized decisions without the instability accompanying decentralized financial markets. (Minsky 1982, p. 86)

\section{The Risk Channel: Margin of Safety}

By putting banks and investors at the center of his theory, Minsky also introduced elements of uncertainty into his theory of instability. Both lenders and borrowers build some "margin of safety" into their calculations based on their expectations of the future. This is in sharp contrast to many of today's macro models that still assume that the risk premia are either constant or do not exist; and that therefore asset prices, and so wealth and the cost of capital, are influenced only by changes in the expected path of the risk-free rate and in the cash flows expected from investments (Tucker 2012, p. 8). 
Borio and Zhu (2008) add that such models most often restrict the range of mechanisms through which risk perceptions and tolerance can influence behavior.

Sometimes, the only source of risk is idiosyncratic to firms. More often than not, users of funds treat the risk of projects as exogenous and have no incentive to insure against losses from bankruptcy. Similarly, providers of funds, be these the ultimate providers or the intermediaries, are often assumed to be risk-neutral or to be able to diversify risks perfectly. Hence, often risk premia are either absent or exogenously given. (Borio and Zhu 2008, p. 8)

And since these models adopt the simplifying assumptions of model-consistent (rational) expectations and an absence of co-ordination failures, there is no room whatsoever for overexuberance, disappointments, or bankruptcies. This is in sharp contrast to Minsky's instability theory, where investment is determined jointly by "lender's risk" and "borrower's risk." The demand for investment is not just a reflection of the technical productivity of capital assets; rather it summarizes the behavior of technical, marketing, and financial influences (Minsky 1986, p. 214, 218). "Investment therefore is a financial phenomenon. The various parts of the investment decision can be illustrated to show how different factors are interrelated and how asset prices, financing conditions, and income flows affect investment" (Minsky 1986, p. 209).

Minsky notes that investments will be influenced by the borrowers' willingness to go into debt and the lenders' willingness to finance leveraged positions. "As Keynes put it, our economy is characterized by 'a system of borrowing and lending based upon margin of safety"” (Minsky, 1986, 207-8). The margins of safety required by both the borrowers and the lenders affect the extent to which positions and investments are externally financed. This "risk channel" of investment is key to Minsky's Financial Instability Hypothesis.

\section{A “NEW” VIEW OF BANKING}

The GFC has led to a broad-based reassessment of the current central banking paradigm and to calls for an update of the theoretical models used by policymakers. Gillian Tett notes that "the crisis has tossed central banking into an intellectual limbo," ${ }^{72}$ and a recent Brookings Institute report calls for an end to the strict separation between monetary and financial policy analysis

${ }^{72}$ Gillian Tett, "Central bankers must update outdated analytical toolkit,” Financial Times, October 20, 2011 http://www.ft.com/intl/cms/s/0/877b7bfa-fb21-11e0-bebe-00144feab49a.html\#axzz1qbbtd356. 
(Brookings Institute 2011, p. 7). Still, changing the prevailing paradigm will not be easy, since many of the issues now facing us are new and unfamiliar. Gorton and Metric (2012) admit that "many professional economists now find themselves answering questions from their students, friends, and relatives on topics that did not seem at all central until a few years ago, and we are collectively scrambling to catch up [italics added]" (Gorton and Metric 2012, p. 1).

It should then be comforting that many of the issues raised by the crisis, such as the massive leverage and credit expansion, the growth of the shadow banking system, and the instability of capitalism have been studied for decades by economists trained in the tradition of J. M. Keynes and Hyman Minsky. However, as Friedman (2012, p. 303) notes, embracing some of their insights may be hard, as it would undercut some of the key assumptions of the current policy models, like full model-rationality and the inherent stability of markets. As Minsky (1986, p. 281) notes: "If the disrupting effects of banking are to be constrained, the authorities must drop their blinders and accept the need to guide and control the evolution of financial usages and practices."

Tinkering at the margins of older models or adding some frictions to newer ones will not do the trick. A more wholesale revision is needed. This will require mainstream economists to look outside their traditional group of referees and study older economic thoughts and listen to newer, non-traditional voices. ${ }^{73}$ Epstein (2012) notes that it is odd how mainstream economists fail to address these issues (of financial instability) ex ante, but then scramble ex post to make some adjustments to their equilibrium models, rediscovering the issues that non-traditional economists have been occupied with all along. However, as memories of the last crisis fade, these unpleasant facts are soon forgotten and policy and modeling are back on the traditional track again. $^{74}$

Borio and Disyatat (2011, p. 27) from the BIS make a strong plea for a change of theoretical direction:

\footnotetext{
73 The Soros sponsored Institute for New Economic Thinking is one such avenue for alternative economic thinking. The Levy Economics Institute is another.

${ }^{74}$ Paul Tucker (2012, p. 2) admits to having served on a committee together with Mario Draghi after the Asian crisis that produced a report (Report of the Working Group on Capital Flows) that recommended much tighter monitoring of national balance sheets in order to prevent another crisis. These insights were unfortunately forgotten, but need to be recaptured, according to Tucker.
} 
The distinguishing characteristic of our economies is that they are monetary economies, in which credit creation plays a fundamental role. The financial system can endogenously generate financing means, regardless of the underlying real resources backing them. In other words, the system is highly elastic. And this elasticity can also result in the volume of financing expanding in ways that are disconnected from the underlying productive capacity of the economy. In macroeconomic models, the role of money and credit should be essential, not ancillary. This calls for a revival of an old and highly respected tradition in macroeconomics - one which, sadly, has been largely neglected in the current prevailing paradigm.

Even a New Monetarist like Stephen Williamson supports their call for a better theoretical platform when he notes that

we need more serious research on central bank lending, when [such lending] is appropriate and when it is not, what is appropriate collateral for a central bank loan, what are appropriate collateral haircuts, and what is the role of central bank lending relative to conventional and unconventional open market operations, etc. ${ }^{75}$

The revival of "an old and highly respected tradition in macroeconomics" would include the insights of Thornton and Wicksell, supplemented with the views of the older Chicago School, Keynes, Kindleberger, and Minsky (just to mention a few). Their theories should form the basis of a "new" view of banking that acknowledges the instability of markets and the ability of banks to create money. ${ }^{76}$ Putting these insights at the center of a new research agenda will be essential for developing policies for a better financial future. The following key insights should guide our work:

- The banking system is highly procyclical and capable of generating endogenous credit cycles.

o Banks create money, by extending credit - they are not intermediaries!

o Collateralized lending amplifies the procyclicality

- The shadow banking system is expanding on the false assumption of CB support

o Liquidity illusion is everywhere

o The market is very elastic and has grown out of proportion

\footnotetext{
${ }^{75}$ Stephen Williamson, "Discount Window Lending, Secrecy, and Stigma," Stephen Williamson: New Monetarist Economics (blog), December 3, 2011 http://newmonetarism.blogspot.com/2011/12/discount-window-lendingsecrecy-and.html.

76 "New" for traditional economists, but actually old views for economists in the Keynesian and Minsky tradition.
} 
- Central banks cannot and should not be expected to provide liquidity support to all market segments; the MMLR role needs to be limited.

o There should be congruence between responsibility and control

o The Fed cannot validate all euro-money debt; review of swap line policy

- Economic theory has not been alert to these features of our modern economy.

o Highly stylized models with representative agents and no credit

o Need for more realism and institutional details of unstable finance

- Financial regulatory policy needs to be more reflective of these insights:

o Markets will not find their equilibrium if left to themselves

o Changing risk weights may not be sufficient to create stability

- Cross-border banking represents an especially challenging area.

o Global banks should not be allowed to expand at current pace

o Final supervisory responsibility needs to be determined

- Who will provide liquidity support in a crisis, home or host country?

Since "crises are inherent in free-market capitalism," replicate such crises. This is not possible within perfect foresight, representative agent models without banks, credit, or default. Such models may be good benchmarks for how to get to perfect markets, but in the meantime, we should work hard to understand how our unstable monetary economies with deep uncertainty actually perform. Drawing on the insights of Wicksell, Keynes, and Minsky, we need to build models that can restore the link between finance and the real economy. This is a prerequisite for developing polices to deal with the instability of credit. As Minsky observed more than thirty years ago:

The financial instability hypothesis has policy implications that go beyond the simple rules for monetary and fiscal policy that are derived from the neoclassical synthesis. In particular the hypothesis leads to the conclusion that the maintenance of a robust financial structure is a precondition for effective antiinflation and full employment policies without a need to hazard deep depressions. This implies that policies to control and guide the evolution of finance is necessary [italics added]. (Minsky 1982, p. 92)

\footnotetext{
${ }^{77}$ Martin Wolf, “The world's hunger for public goods," Financial Times, January 24, 2012.
} 


\section{POLICY ISSUES}

The crisis exposed serious flaws in the pre-crisis policy framework and forced policymakers to rethink the current architecture of macroeconomic policy (Blanchard 2010, p. 16). Paul Tucker is more direct when he admits that: "Plainly, finance got out of hand!" (Tucker 2012, p. 10).

Central banks employed highly unconventional policies to avoid a systemic meltdown and, in the process, stretched Bagehot's advice, to "lend freely at high rates against good collateral" to the limit. In the process, they became quasi-fiscal agents for the Treasury, providing financial support to highly-levered financial institutions that could not be closed without systemic consequences. In the process, the symbiotic relationship between the treasuries and central banks were exposed, raising questions about the possibility of truly independent central banks.

During the GFC, central banks' balance sheets were used to plug the holes of dysfunctional markets. The scale of intervention was unprecedented. Initially much of this support was sterilized, but when central banks recognized that interest rate policy (in reality ZIRP) could be executed while their balance sheets expanded, this policy of sterilized interventions stopped. We then entered a new phase of quantitative easing without full sterilization, and central banks' balance sheets exploded. This was the visible sign of the unconventional monetary policies. But it is important to recognize that the huge liquidity support with sterilization was equally problematic, even though the impact on primary liquidity was different.

The strong growth in global liquidity before and even after the GFC has revealed the endogenous nature of private credit. Bank credit has been fueling the growth of the shadow banking system, based on a combination of repo lending, securities lending, and rehypothecation. The market growth is so strong that many are questioning the wisdom of central banks unconditionally backstopping the system. As Hannoun (2012) notes, central banks are increasingly seen by market participants as all-powerful, able to intervene without any limit: the belief is that they can always counteract the fallout of a financial crisis by keeping policy rates near zero as long as necessary; 
and that they can intervene in an unlimited way as lender of last resort for both banks and sovereigns. (Hannoun 2012, p. 5)

If this impression is left with market participants, moral hazard will again emerge and lead to even greater leverage and financial fragility (Ibid., p. 8). This tension between an anchorless private credit system and the expectation of central bank liquidity support in times of crisis has been the main topic of this paper.

In my view, there must be some limit to how far central banks should go in supporting financial markets in a crisis, especially when much of the expansion prior to the crisis has been based on the "liquidity illusion" that markets were safe and would eventually be supported by central banks - almost for free. Even when the central bank has the ability to create unlimited official liquidity, there should be some limits to its support of the financial sector. ${ }^{78}$

\section{Limits to Central Bank Liquidity Support}

The crisis has forced central banks to extend the scope and scale of their traditional role as lenders of last resort. They broadened their liquidity support to non-deposit-taking institutions and intervened directly (with purchases) or indirectly (through acceptance of non-traditional assets as collateral) in a broad range of asset markets (Blanchard 2010, p. 14). Some would like to see central banks embrace this new role as market maker of last resort permanently, while others would like to see their central banks move permanently into the newly discovered areas of quantitative easing. However, some central bankers are feeling distinctly uncomfortable about the longer-term implications of such large balance sheets (Caruana 2011, p. 5). The Bundesbank has recently voiced its concern that the ECB is straying beyond being a lender of last resort into a prop for failing banks without suitable security. ${ }^{79}$

The current policy discussion relates to fundamental principles of central banking. According to Andrew Sheng, "at the heart of the current debate is whether central banks, as agents for monetary discipline, should re-impose the hard budget constraint on global fiat money and by what rule?" (Sheng 2011, p. 14).

\footnotetext{
${ }^{78}$ Central banks in a monetary union will be constrained in their autonomous creation of liquidity.

79 James Wilson and Claire Jones, “Southern discomfort fuels German unease,” Financial Times. March 1, 2012. http://www.ft.com/intl/cms/s/0/04726188-63c7-11e1-8762-00144feabdc0.html\#axzz1qbbtd356
} 
But is it reasonable to impose strict limits on official liquidity expansion while private credit remains unconstrained? As Borio and Disyatat (2011) have noted,

The fundamental weaknesses in the international monetary and financial system stem from the problem of 'excess elasticity': the system lacks sufficiently strong anchors to prevent the build-up of unsustainable booms in credit and asset prices (financial imbalances) which can eventually lead to serious financial strains and derail the world economy. (Borio and Disyatat 2011, p. 27)

We should therefore start by exploring ways to limit the unconstrained growth of private liquidity before we impose severe limitations on central bank official liquidity. After all, the provision of an elastic (official) currency is one of the key functions of central banks in a crisis. We need to find the right balance between the legitimate requirements for market support in a crisis and unwarranted central bank support for past excesses.

\section{Policy Proposals}

The shocks of the GFC made the case for reform urgent. Banks need far more capital and better liquidity buffers. We also need resolution regimes that enable banks to close without systemic consequences. Separating retail banking and proprietary trading will certainly help. But according to Wolf (2012a), there are unfortunately no simple remedies and progress will be slow, given the vast scale of finance and the strong lobbying forces. As Nersisyan and Wray (2010) point out:

Bank balance sheets haven't been simplified, financial institutions haven't been restructured, and concentration problems haven't been resolved. The only changes that have taken place have been superficial and have contributed to making the system even more fragile. Debts are still at historically high levels. The four largest US banks have derivatives on their balance sheets, which are thousands of times more than their assets. The fundamental causes of the crisis haven't been addressed; the system today is in a worse shape than it was prior to the crisis. (Nersisyan and Wary 2010, p. 26)

\section{Basel III Is Not Enough}

The official policy response of the G20, the Financial Stability Board (FSB), and the Basel Committee of Banking Supervisors (BCBS) has been laid out as a multi-year program that will 
strengthen banks' balance sheets, improve their liquidity positions, and in general make them more robust. This will reduce the need for future liquidity support from central banks.

Improving crisis resolution policies and forcing banks to prepare "living wills" should also enable authorities to intervene more forcefully in a crisis without having to use taxpayer's money or rely on central banks' liquidity support. ${ }^{80}$ Implementing the Volcker rule in the US and the proposals for "ring-fencing" banks' retail operations in the UK ("the Vickers proposals") would also help. Then there are initiatives to shift derivatives trading onto central counterparties and reform the tri-party repo market. And this year (2012) the Basel Committee and the FSB will review policies for banks' trading books and policies for the shadow banking sector.

This is a broad regulatory agenda and, if fully implemented, it would certainly make the financial sector a lot safer. The problem is partly that the implementation schedule has been stretched so far into the future that it will take several years before the full impact of the reforms will be felt. And the basic building blocks of the reforms are still the risk-weighted formulas of Basel II. But policymakers are increasingly realizing that this framework has serious drawbacks, and that "it was very obviously a false step when, in Basel 2, the international-standard setters tried to follow the techniques and calibrations of private sector risk managers rather than engaging with the externalities that warrant State intervention in the first place" (Tucker 2011, p. 4).

There is a real risk that the ongoing reforms under the official Basel III umbrella will be too timid and too late. Currently, much of the focus is on capital, liquidity, and macro prudential measures, like the countercyclical capital buffer. Tucker (2012) suggests: "We need macro prudential regimes to ensure the resilience of the financial system” (Tucker 2012, p. 12). Turner (2011) also supports "higher equity capital requirements, and macro-prudential policies which can respond in a discretionary fashion to the credit cycles” (Turner 2011, p. 30). And Cœuré (2012) from the ECB wants micro- and macro-prudential measures that can "break the selfreinforcing interaction between risk appetite and liquidity," including of course the liquidity and capital adequacy-related measures which are at the heart of the Basel III accord (Cœuré 2012).

\footnotetext{
${ }^{80}$ Progress is slow, though; FT reports on March 4 that "Banks drag feet on living wills."
} 
In addition, Cœuré would like to see

further improvements in the financial regulatory framework that would enable national supervisors and central banks to better monitor and, if necessary, rein in endogenous liquidity creation within the financial sector. This includes the oversight and regulation of the shadow banking system and the implementation of OTC derivatives market reform. ... Progress along these three avenues would help to provide a consistent policy framework for addressing global liquidity. (Couré 2012)

It remains to be seen how effective the new macro-prudential tools will be in constraining private credit expansion in the next boom. There is a distinct risk that they may be too weak and kick in too late. And in the meantime, the shadow banking system keeps growing. The most recent policy proposals from the FSB and the BCBS focus primarily on data gathering and monitoring, and will not have any big impact in the foreseeable future. Monitoring is a required first step towards real policy reform. But there is a danger that reform will stop at the monitoring and data collection stage.

\section{Are We Being Radical Enough? ${ }^{81}$}

The "new view of banking" sketched above suggests that we need more radical reform to curb excessive credit growth and make finance a servant of the real economy, and not the other way around. As Turner (2011) notes in a recent lecture (referring to the former ECB central banker Thomasso Padoa-Schioppa):

The question we have not yet answered, he said "was whether this was a crisis of specific institutions or a crisis of markets and systems." A key conclusion of this lecture is that we must understand it as the latter. (Turner 2011, p. 3)

In the recent crisis, central banks and treasuries intervened heavily to prevent a systemic meltdown. It is now commonly agreed that there cannot be a repeat of this spectacular rescue operation. To prevent a repeat of the crisis and to limit the need for central bank liquidity support in the future, the following five additional policies should be considered.

\footnotetext{
${ }^{81}$ Adair Turner: Reforming finance: are we being radical enough? 2011 Clare Distinguished Lecture in Economics and Public Policy.
} 


\section{Impose a Global Leverage Ratio}

The Financial Stability Board should consider implementing a global leverage ratio, based on information collected by national supervisors and aggregated at the BIS, to monitor global liquidity developments. Recognizing that the total amount of global liquidity can become too large, the FSB should set global leverage limits. When these are breeched, national regulators should be asked to tighten their macro-prudential tools to limit the growth of private credit creation and increase haircuts to limit collateral "daisy chains."

The Basel III proposal includes bank-specific leverage ratios. When implemented, these ratios could well become the binding constraint on banks' credit growth. Still, large parts of banks' off-balance sheet activities may not be included. As Pozsar and Singh (2011) note in their work on rehypothecation, "regulators may need to reconsider and fine-tune the leverage definitions of banks to incorporate collateral chains due to the sizable volumes of pledged collateral that churn between banks and nonbanks" (Pozsar and Singh 2011, p. 14). They also suggest that the current unregulated rehypothecation activities of banks in the UK present a big challenge for any future regulation of bank leverage.

Geanakoplos (2010) would also like to see a global "leverage supervisor ... who could simply forbid loans at too high leverage in ebullient times, setting different leverage limits for different security classes." And he adds that, "put bluntly, the market will not take care of outsized leverage alone. It is thus imperative that the Fed put outside limits on leverage" (Geanakoplos 2010, p. 128).

A global leverage ratio would create a link between the bank-specific leverage ratios and the growth of global liquidity, and support the work of national regulators in adjusting the parameters for their macro-prudential tools. Banks would simply not be allowed to lend 100 percent or more of the value of a house, and repo lenders would not be allowed to cut their haircuts too far. 


\section{Divorce the Payment System from Risky Lending Activity ${ }^{82}$}

We need a payment system that can operate through a crisis without taxpayer support, and that will not be used to blackmail the central bank to provide generous liquidity support. This could be done in several different ways, but the two current approaches of Volcker and Vickers will probably not be enough.

Many banks were bailed out during the crisis because authorities were concerned about the negative impact of a closure on the payment infrastructure. As the FSA in the UK noted, "the key thing [of living wills] is protecting the economic functions for which continuity is critical to the economy" (FSA 2011, p. 9). The preparation of Recovery and Resolution Plans (RRP) should, in principle, help banks and regulators determine which parts of the banks are "systemic" and thus worth keeping afloat during a crisis. In practice, it is close to impossible to draw the line between "essential" and not so essential banking services.

The Volcker rule attempts to segregate speculative trading (proprietary trading) and then retain a safer bank that includes the payment function, but also a lot more. The Vickers proposal tries to ring-fence essential retail operations while preventing the narrowed bank from engaging in too much speculative trading. The bottom line is that these initiatives will take years to be implemented, and they will run into a lot of detailed discussion on the margins, but will not resolve the bigger issue of how to protect the core payment system function in a crisis.

An alternative and better way has been proposed by Tobin (1987). He suggested that we need a new payment system based on "deposited currency" guaranteed by the state (Tobin 1987, p. 172). This would be a sort of electronic cash system (i.e., retail "Federal Funds" system) that the public could use to perform essential banking services. ${ }^{83}$ Commercial banks would remain almost as they are today, except for some restrictions on proprietary trading, which would be left to investment banks. Commercial banks would continue offering guaranteed deposit accounts (up to a limit) and payment services. The noteworthy feature of his proposal is that, by establishing a competitive public payment system, the banks cannot claim to be indispensable in a crisis. This will enable authorities to close troubled banks without systemic consequences. It

\footnotetext{
${ }^{82}$ See Dyson et al. (2011) for details of a twenty-first century banking and monetary system based on this proposal.

${ }^{83}$ The system could be run on a commission basis by private banks, or could be run by the central banks themselves.
} 
will be hard to deal with the persistent problem of TBTF unless something like this alternative payment infrastructure is established.

\section{Limit the MMLR Role of Central Banks: A New Bagehot Rule}

We need a new "Bagehot Rule" to guide central bank liquidity support in future crises. Central banks should not embrace the new role of market maker of last resort unconditionally. Banks and other financial institutions should be told in clear terms that liquidity support will not be provided for speculative activities. It follows that central banks will need a strong mandate to constrain speculative activities among banks in the upswing, if liquidity support is to be provided in the downswing. A fall in asset prices should not be an automatic trigger for central bank liquidity support. ${ }^{84}$

Meltzer (2011) argues that the lack of a firm rule for lender of last resort policy for the Federal Reserve creates uncertainty and raises questions of hidden motives in a crisis. In addition, Meltzer insists that "absence of a rule encourages failing firms to pressure Congress to pressure the Federal Reserve" (Meltzer 2011, p. 306). A new "Bagehot Rule" could in his view end the "too big to fail" policy of the past thirty years. ${ }^{85}$ That policy promotes gigantism, moral hazard, and encourages excessive risk. A new rule would protect the public and not the large banks.

Goodfriend (2011) would also like to develop new principles for the Federal Reserve's lender of last resort policy as a basis for a new Treasury-Fed "accord" (Goodfriend 2011, p. 9). This would clarify and limit the Fed's ability to engage in quasi-fiscal operations while preserving its independence on monetary policy. According to Goodfriend, conventional last resort lending is reasonably compatible with central bank independence. This would involve “occasional, temporary, well-collateralized ordinary last resort lending to solvent, supervised depository institutions. Any other support beyond this would only be undertaken after prior agreement with the Treasury" (Goodfriend 2011, p. 9).

\footnotetext{
${ }^{84}$ Like the "Greenspan put."

${ }^{85}$ Anna Schwartz (1992) observed that: "The Penn Central episode [of 1970] fostered the view that bankruptcy proceedings by a large firm created a financial crisis, and that, if possible, bankruptcy should be prevented by loans and loan guarantees: the 'too big to fail' doctrine in embryo."
} 
Liquidity support from central banks cannot (and should not) be put on auto-pilot. In a crisis, the only source of an elastic currency is the central bank. Still, the integrity of the central bank should be protected against uncontrolled market forces that have the potential to wreak havoc not only with the central bank's balance sheet, but also the government's finances. The best solution to this dilemma has been provided by Minsky, who supported an elastic currency in the midst of a crisis (when all other options have been exhausted), but combined this flexible policy with tough regulatory measures both before and after the crisis. As he argued (1986), "Clearly, central bank lender-of-last-resort interventions must lead to legislated or administered changes that favor hedge financing and ... the central bank should continuously 'lean against' the use of speculative and Ponzi financing" (Minsky 1986, p. 364).

\section{Enforce Tougher Collateral Rules in Central Banks}

Central banks should establish tougher collateral rules to prevent banks from posting "cheap" collateral. This practice has enabled banks to engage in "daisy chains" of securities lending that have added to fragility. For a tighter collateral policy to be credible, central banks must back it with policies that reduce the speculative behavior of banks so that the current elasticity of the private credit system is reduced. ${ }^{86}$

The "real bills doctrine" represented an attempt to limit bank credit to the needs of the real economy (Humphrey 2001, p. 175). By limiting the type of paper eligible for rediscount, the Federal Reserve ensured that reserves were just sufficient to underwrite production without promoting speculation. But this strict policy had to be revised in the early 1930s when the Federal Reserve's supply of liquidity was severely constrained by the shortage of eligible paper among banks. The new banking legislation in 1933 and 1935 laid the basis for the "Treasuries only" policy that is still adhered to by many central banks (including the Bank of England).

The experience of the Federal Reserve in the 1930s illustrates the challenges of a tight collateral policy. Reinstating a strict "real bills" policy today would probably not be wise. Still, there is something intuitively appealing about the doctrine, as it would redirect bank lending toward the needs of the real sector and away from short-term speculative trading activities.

\footnotetext{
${ }^{86}$ As well as implementing policies that will divorce essential payment functions from banks, as noted above.
} 
Minsky (1986) was clearly inspired by the real bills doctrine when he noted that "the Federal Reserve should stop relying upon open-market operations to determine reserves of the banking system. As an alternative, the Federal Reserve can furnish bank reserves by discounting bank assets" (Minsky 1986, p. 361-365). The central bank would buy or lend on specific, eligible types of paper that are the result of financing business. To assess the quality of the posted collateral, central banks "would have the right to look over the shoulder and comment of the adequacy of bank's lending practices. Too great a growth of ineligible paper would mean a review of the availability of credit for that bank" (Minsky 1986, p. 361-365). For Minsky, supervision was a natural extension of the central bank's discounting policy.

The bottom line is that central banks have a clear interest in the balance sheets of their "clients" and therefore a legitimate reason to be intrusive with regard to the lending practices of banks. This holds even if the central bank is not the formal supervisor of banks. Tighter collateral rules need to be accompanied with a more pro-active "lean against the growth of ineligible paper" policy.

\section{Stop the “Too Big Too Fail” Policy}

Regulators should also enforce size limits on the largest Systemically Important Financial Institutions (SIFIs). FSB could propose an international accord to limit the size of the largest global banks. This should be done independently of ongoing initiatives to reduce proprietary trading or impose systemic capital surcharges on these institutions. Only tough anti-trust regulation can break the persistent trend toward greater concentration.

The recent crisis has resulted in even bigger banks. In the US, half of the entire banking industry's assets are now on the books of five institutions (Fisher 2011). This has resulted in "a few financial behemoths each with well over a trillion dollars in assets and a heavy concentration of power" (Ibid.).

As Minsky (1985) observed, "If a bank is too big, the central bank cannot stand aside and allow a bank to fail." He suggested that "there is a maximum size to a bank that is consistent with the Federal Reserve being able to stand aside in the individual case, intervening as a lender of last resort only when markets are in crisis." This maximum size might "in today's 
economy set a ten billion dollar limit to the size of any bank" (Minsky 1985, p. 18). However, Minsky was not too optimistic about enforcing this size limit and concluded therefore (somewhat resignedly) that the Federal Reserve will continue to support giant banks in distress.

The Dodd-Frank Act contains several sections that are intended to deal with the problem of too big too fail, including enhanced capital requirements for SIFIs and the Orderly Liquidation Authority. Still, there are those who doubt whether Dodd-Frank will be enough to deal adequately with the problem. Governor Fisher of the Federal Reserve Bank of Dallas has recently voiced his concern, noting that the only fail-safe way to deal with the too big to fail is "to get an international accord that would break up these institutions" (Federal Reserve Bank of Dallas, 2012).

The challenge of handling a potential failure in one of these banking behemoths, with branches and subsidiaries in several countries, should in itself lead to more drastic action now. Despite continuous discussions in the Basel Committee since its inception in the mid-1970s, regulators still cannot agree about "who is responsible for what in a crisis." Current work on living wills and crisis resolution may lead to some improvements, but the odds are low. In the meantime, global banks are expanding under the cover of limited liability and unclear regulatory responsibilities. This situation should not be allowed to prevail for much longer.

\section{Endnote: Can Central Banks Remain Independent?}

The performance of central banks during the GFC has raised legitimate questions about their continued independence, particularly in those countries where the quasi-fiscal nature of the liquidity support was most glaring (Goodfriend 2011). In most countries, central bank support for failing financial institutions and markets was provided in close coordination with the respective treasuries. But the transition from crisis manager to quantitative easer has been subtle, and the relative roles slightly diffuse. The recent expansion of balance sheets by way of quantitative easing is considered by most central banks to be monetary policy, and therefore not part of the "crisis dialogue" with the treasuries. 
The explosive expansion of balance sheets in some central banks has, however, raised concerns among some central bankers about the sustainability and effectiveness of the current policy. Hannoun (2012) warns:

Avoiding fiscal dominance will require decisive steps by central banks, but also by other policymakers. Central banks will need to restore a clearer separation between monetary and fiscal policy. The central bank has a monopoly over interest rate policy, but not over balance sheet policy. Almost any balance sheet policy of the central bank could be replicated by the government. Conversely, any balance sheet policy the central bank implements has an impact on the consolidated government sector balance sheet. Balance sheet policy needs to be viewed as part of this larger balance sheet. As a consequence, the line between monetary and fiscal policy becomes blurred when the central bank continuously engages in balance sheet policies. (Hannoun 2012, p. 20)

Hannoun urges central banks to refocus on their price stability mandate and limit their roles in balance sheet repair and real economy adjustments (Ibid., p. 21).

Sheng (2011) is also concerned about the current balance sheet expansions and notes that "central banking remains an art precisely because it is an anchor of public trust in fiat money. Unless current reserve currency economies do not restore fiscal and monetary discipline, then inflation and the flight into gold will continue" (Sheng 2011, p. 14).

Hannoun (2012) adds that "the line between monetary and fiscal policy becomes blurred when the central bank continuously engages in balance sheet policies.... Ultimately this may give rise to the impression that they are monetizing the public debt" (Hannoun 2012, p. 20). And Borio (2011) agrees that "central banks need to consider that large-scale purchases of government bonds may ultimately give rise to the impression that they are monetizing the public debt" (Borio 2011, p. 12).

As Sheng (2011) and Goodfriend (2011) have noted, a review of central banks' liquidity support policies during and after the GFC raises fundamental issues of central banking, such as the independence of central banks, their lender of last resort role during crises and during more normal times, the effectiveness of their policies, and the need for coordination with the government's fiscal and debt management policies. This paper has indirectly touched on some of these issues, even though they have not been the main focus of the paper. 
Central banks are defending their independence vigorously, even though the crisis exposed the symbiotic nature of the central bank-treasury relationship. Borio (2011) correctly notes that the aggressive balance-sheet policies inevitably blur the line between monetary and fiscal policy and that this could lead to a discussion of which central bank functions, if any, should remain independent. As Friedman observed in 1948, in theory, most central bank functions could just as well be implemented in a treasury office.

The period ahead will determine whether central banks can retain their operational independence, or even expand it into the realm of macro-prudential policies. Borio warns about the current threats to central bank independence and would like to see "stronger safeguards" to preserve independence (Borio 2011). These are, however, challenging times, and the GFC has shown that no policy should be set in stone. If the current policy of massive quantitative easing does not work, or if collateral values fall dramatically, there could be material effects on central banks' balance sheets and therefore indirectly on taxpayers' (future) funds. This will invariably raise questions about the current division of labor between central banks and treasuries, and the wisdom of central banks' massive liquidity support.

Currently central banks are stretched between the liquidity demands from a private credit system out of control and the reactions of the public and politicians to what is perceived as excessive liquidity support. It is too early to tell how central banks will manage this balancing act and what consequence it may have for central banks' independence. But as Ugolini (2011) notes, "Central banks would be wise not merely to defend the status quo" (Ugolini 2011, p. 24). He adds that central bank organizations have varied over the years, and

as one connoisseur pointed out during another period of great economic transformation, 'the cardinal virtue of the central banker is not conservatism in technique, but rather a disposition to discover novelties and to be versatile in technique' (Sayers 1949, p. 211). On the other hand, before indulging in destabilizing attacks, politicians should never forget how much the very functioning of states depends on central banks and their action within the banking system: as one major Venetian banker argued during the big financial crisis of 1498, 'quando i banchi no ha' fede, la Terra no ha credito [when there is no trust in the banking system, there is no credit for the Country]' (Mueller 1997, p. 425) 


\section{REFERENCES}

Adrian, Tobias and Hyun Song Shin. 2009a. "The Shadow Banking System: Implications for Financial Regulation.” Staff Report No. 382. Federal Reserve Bank of New York.

—. 2009b. "Financial Intermediaries and Monetary Economics." Staff Report No. 398. Federal Reserve Bank of New York. Revised May 2010.

_. 2009c. "Money, Liquidity, and Monetary Policy." Staff Report No. 360. Federal Reserve Bank of New York.

Adrian, Tobias, B. Begalle, A. Copeland, and A. Martin. 2011. "Repo and Securities Lending." Staff Report No. 529. Federal Reserve Bank of New York.

Bagehot, Walter. 1873. Lombard Street: A Description of the Money Market. London, UK: Henry S. King and Co.

Bernanke, Ben S. 2009. "Federal Reserve Programs to Strengthen Credit Markets and the Economy." Testimony before the Committee on Financial Services, U.S. House of Representatives. February 10, 2009.

Berry, Stuart, R. Harrison, R. Thomas, and I. de Weymarn. 2007. "Interpreting Movements in Broad Money." Quarterly Bulletin, Q3. Bank of England. http://www.bankofengland.co.uk/publications/Documents/quarterlybulletin/qb070302.pd $\mathrm{f}$

Bank for International Settlements. 2007. "Monetary Policy Frameworks and Central Bank Market Operations." Document prepared by the members of the Markets Committee.

—. 2001. "Review of Issues Relating to Highly Leveraged Institutions (HLIs)." Basel Committee on Banking Supervision and the International Organization of Securities Commissions.

Bezemer, Dirk J. 2009. “'No One Saw This Coming': Understanding Financial Crisis Through Accounting Models." Working Paper No. 15892. Munich, Germany: Munich Personal RePEc Archive.

Bindseil, Ulrich and J. Lamoot. 2011. "The Basel III Framework for Liquidity Standards and Monetary Policy Implementation.” SFB 649 Discussion Paper 2011-041, Berlin, Germany: Humboldt University.

Blinder, Alan S. 2012. "Revisiting Monetary Policy in a Low-Inflation and Low-Utilization Environment." Journal of Money, Credit and Banking 44, Supplement s1: 141-146. 
Board of Governors of the Federal Reserve System. 2009. "The Role of the Federal Reserve in

Preserving Financial and Monetary Stability." Joint Statement by the Department of the Treasury and the Federal Reserve. March 23, 2009.

http://www.federalreserve.gov/newsevents/press/monetary/20090323b.htm

. 2011a. "Guide to the Federal Reserve's Payment System Risk Policy on Intraday Credit." http://www.federalreserve.gov/paymentsystems/files/psr_guide.pdf

- 2011b. Letter to Congress, December 6, 2011.

http://www.federalreserve.gov/generalinfo/foia/emergency-lending-financial-crisis20111206.pdf

Borio, Claudio. 2011. "Central Banking Post-Crisis: What Compass for Uncharted Waters?" Working Paper No. 353. Basel, Switzerland. Bank for International Settlements.

Borio, Claudio and P. Disyatat. 2011. "Global Imbalances and the Financial Crisis: Link or No Link?” Working Paper No. 346. Basel, Switzerland. Bank for International Settlements.

Borio, Claudio, B. Vale and G. von Peter. 2010. "Resolving the Financial Crisis: Are We Heeding the Lessons from the Nordics?” Working Paper No. 311. Basel, Switzerland. Bank for International Settlements.

Brookings Institute. 2011. "Rethinking Central Banking." Committee on International Economic Policy and Reform.

http://www.brookings.edu/ /media/Files/rc/reports/2011/09_ciepr_central_banking/Reth inking\%20Central\%20Banking.pdf

Bruno, Valentina and H. S. Shin. 2012. "Capital Flows, Cross-Border Banking and Global Liquidity.”http://www.princeton.edu/ hsshin/www/capital_flows_global_liquidity.pdf

Buiter, Willem and A. Sibert. 2007. "The Central Bank as the Market-Maker of Last Resort: From Lender of Last Resort to Market-Maker of Last Resort.” In A. Felton and C. M. Reinhart, The First Global Financial Crisis of the $21^{\text {st }}$ Century. VoXEU.org.

Buiter, Willem. 2008a. “Can Central Banks Go Broke?” Policy Insight No. 24. London, UK: Centre for Economic Policy Research. http://www.cepr.org/pubs/policyinsights/PolicyInsight24.pdf

- 2008b. “Central Banks and Financial Crises.” Kansas City, MO: Jackson Hole Symposium, Federal Reserve Bank of Kansas City. http://www.kansascityfed.org/publicat/sympos/2008/Buiter.03.12.09.pdf

Cagler, Evren, J.S. Chadha, J. Meaning, J. Warren, and A. Waters. 2011. "Non-Conventional Monetary Policies: QE and the DSGE Literature." Studies in Economics 1110. Kent, UK: Department of Economics, University of Kent. 
Caruana, Jaime. 2011. "Why Central Bank Balance Sheets Matter." Keynote address at Bank of Thailand-BIS Conference. http://www.bis.org/speeches/sp111216.pdf

Cecchetti, Stephen G. 2008. "Crisis and Responses: The Federal Reserve and the Financial Crisis of 2007-2008." Working Paper No.14134. Cambridge, MA: National Bureau of Economic Research.

Chadha, Jagjit. 2010. "Quantitative Easing - A Mid-Term Review." Cambridge, UK. Centre for International Macroeconomics and Finance, University of Cambridge. http://www.york.ac.uk/res/mmf/documents/QE.pdf

Chailloux, Alexandre, S. Gray, and R. McCaughrin. 2008. "Central Bank Collateral Frameworks: Principles and Policies.” IMF Working Paper 08/222. Washington, D.C.: International Monetary Fund.

Cheun, Samuel, I. von Köppen-Mertes, and B. Weller. 2009. "The Collateral Frameworks of the Eurosystem, the Federal Reserve system and the Bank of England and the Financial Market Turmoil.” ECB Occasional Paper No. 207. Frankfurt, Germany: European Central Bank.

Committee on the Global Financial System. 2001. "Structural Aspects of Market Liquidity from a Financial Stability Perspective.” Discussion note prepared for the March 2001 meeting of the Financial Stability Forum. http://www.bis.org/publ/cgfs_note01.pdf

—. 2011. "Global Liquidity - Concept, Measurement and Policy Implications." CGFS Paper No. 45. http://www.bis.org/publ/cgfs45.pdf

Cossin, Didier; F. Gonzales, Z. Huang, and D. Aunon-Nerin. 2002. "Establishing Consistent Collateral Policies for Central Banks' Open Market Operations." Working Paper No. 4. Swiss National Science Foundation.

Cœuré, Benoît. 2012. "Global Liquidity and Its International Repercussions." Speech at the BIS-ECB Workshop on Global Liquidity and Its International Repercussions. February $6,2012$.

de Grauwe, Paul. 2011. "The European Central Bank: Lender of last resort in the government bond markets? CESIFO Working Paper No. 3569. Munich, Germany: Center for Economic Studies and Ifo Institute for Economic Research.

de Long, Brad. 2011. "Lend Freely But at a Penalty Rate!!” Blog post, November 30. Grasping Reality with the Invisible Hand. http://delong.typepad.com/sdj/2011/11/yes-the-usgovernment-ought-to-own-the-banks-now.html

Domanski, Dietrich, I. Fender and P. McGuire. 2011. “Assessing Global Liquidity.” BIS Quarterly Review, December. http://www.bis.org/publ/qtrpdf/r_qt1112g.pdf 
Dyson, Ben, T. Greenham, J. Ryan-Collins, and R. A. Werner. 2011. "Towards a Twenty-First Century Banking and Monetary System." Submission to the Independent Commission on Banking. http://www.neweconomics.org/sites/neweconomics.org/files/SubmissionICB-Positive-Money-nef-Soton-Uni.pdf

ECB. 2011. "ECB Announces Measures to Support Bank Lending and Money Market Activity." Press release. http://www.ecb.int/press/pr/date/2011/html/pr111208_1.en.html

ECB. 2012. "ECB's Governing Council Approves Eligibility Criteria for Additional Credit Claims.” Press release. http://www.ecb.int/press/pr/date/2012/html/pr120209_2.en.html

Federal Reserve Bank of Dallas. 2012. "Choosing the Road to Prosperity - Why We Must End Too Big to Fail - Now.” 2011 Annual Report.

Felkerson, James. 2011. \$29,000,000,000,000: A Detailed Look at the Fed's Bailout by Funding, Facility, and Recipient." Working Paper No. 698. Annandale-on-Hudson, NY: Levy Economics Institute of Bard College.

Financial Stability Board. 2009. "Principles for Sound Compensation Practices, April." http://www.financialstabilityboard.org/publications/r_0904b.pdf

_. 2011. "Shadow Banking: Strengthening Oversight and Regulation.” October. http://www.financialstabilityboard.org/publications/r_111027a.pdf

Fisher, Irving. 1933. Stamp Scrip. New York, NY: Adelphi.

Fisher, Paul. 2011. “Central Bank Policy on Collateral.” Bank for International Settlements. http://www.bis.org/review/r110419b.pdf

Fisher, Richard W. 2011. "Taming the Too-Big-to-Fails: Will Dodd-Frank Be the Ticket or Is Lap-Band Surgery Required?” Remarks before Columbia University's Politics and Business Club, November 5. http://dallasfed.org/news/speeches/fisher/2011/fs111115.cfm

Friedman, Benjamin. 2012. "Monetary Policy, Fiscal Policy, and the Efficiency of Our Financial System: Lessons from the Financial Crisis." International Journal of Central Banking, January Supplement. http://www.ijcb.org/journal/ijcb12q0a20.pdf

Friedman, Milton. 1948. "A Monetary and Fiscal Framework for Economic Stability.” The American Economic Review 3: 245-264

Geanakoplos, John. 2010. "Solving the Present Crisis and Managing the Leverage Cycle." Federal Reserve Bank of New York Policy Review, August. http://www.ny.frb.org/research/epr/10v16n1/1008gean.pdf 
Goodfriend, Marvin. 2011. "Central Banking in the Credit Turmoil: An Assessment of Federal Reserve Practice.” Journal of Monetary Economics 58 (1): 1-12.

Goodhart, Charles. 1999. "Myths about the Lender of Last Resort." International Finance 2 (3): 339-360.

Goodhart, Charles A. E. and D. P. Tsomocos. 2011. "The Role of Default in Macroeconomics." IMES Discussion Paper No. 2011-E-23. Tokyo, Japan: Institute for Monetary and Economic Studies.

Gorton, Gary and A. Metrick. 2010. "Haircuts." Yale ICF Working Paper No. 09-15. New Haven, CT: International Center for Finance at Yale.

- 2012. "Getting up to Speed on the Financial Crisis: A One-Weekend-Reader's Guide." NBER Working Paper No. 17778. Cambridge, MA: National Bureau of Economic Research.

Grad, David, P. Mehrling, and D. H. Neilson. 2011. "The Evolution of Last-Resort Operations in the Global Credit Crisis." Paper presented at the Eastern Economic Association Annual Conference.

Gurley, John G. and E. S. Shaw. 1960. Money in a Theory of Finance. Washington, D.C.: Brookings Institution.

Hahn, Frank. 1982. Money and Inflation. Oxford, UK: Basil Blackwell.

Haldane, Andrew G. 2011. "Haircuts." Remarks, Bank for International Settlements. http://www.bis.org/review/r110804d.pdf

Hannoun, Hervé. 2012. "Monetary Policy in the Crisis: Testing the Limits of Monetary Policy." Speech at the $47^{\text {th }}$ SEACEN Governors' Conference: Seoul, South Korea. February 1314, 2012.

Humphrey, Thomas M. 1989. "Lender of Last Resort: The Concept in History." Federal Reserve Bank of Richmond. Economic Review. March/April.

Humphrey, Thomas M. 2001. "Quantity Theory and Needs-of-Trade Measurements and Indicators for Monetary Policymakers in the 1920s." History of Political Economy 33 (1): $162-189$

Humphrey, Thomas M. and R. Timberlake. 2009. "The Federal Reserve's Deviation from Classical Lender-of-Last Resort Theory." Paper presented at the 10th Annual Summer Institute for the History of Economic Thought, University of Richmond: Jepson School of Leadership Studies. 
Independent Evaluation Office of the International Monetary Fund. 2011. IMF Performance in the Run-Up to the Financial and Economic Crisis. Summary of Views of the Advisory Group . http://www.ieoimf.org/ieo/pages/IEOPreview.aspx?img=i6nZpr3iSlU\%3d\&mappingid=dRx2VaDG7E $\mathrm{Y} \% 3 \mathrm{~d}$

International Monetary Fund. 2005. Global Financial Stability Report: Chapter 3: Household balance sheets, April. http://www.imf.org/external/pubs/ft/gfsr/2005/01/

Jácome, Luis I., M. Matamoros-Indorf, M. Sharma, and S.Townsend. 2012. "Central Bank Credit to the Government: What Can We Learn from International Practices?" IMF Working Paper 12/16. Washington, D.C.: International Monetary Fund.

Johnson, Simon and J. Kwak. 2010. 13 Bankers. New York, NY: Random House Press.

Keister, Todd, A. Martin, and J. McAndrews. 2008. "Divorcing Money from Monetary Policy." Federal Reserve Bank of New York Economic Policy Review, September.

Keister, Todd and J. McAndrews. 2009. "Why Are Banks Holding So Many Excess Reserves?" Federal Reserve Bank of New York, Current Issues, December.

Keynes, J. M. 1936. The General Theory of Employment, Interest and Money. New York, NY: Harcourt, Brace \& Co.

Krugman, Paul. 2009. The Return of Depression Economics and the Crisis of 2008. New York, NY: W.W. Norton Company Limited.

Lehmbecker, Philipp. 2008. "The Quality of Eligible Collateral and Monetary Stability." Discussion Paper No. 3. Bremen, Germany: Faculty of Business Studies and Economics, University of Bremen.

Leijonhufvud, Axel. 1997. “The Wicksellian Heritage.” Working Paper 9705. Trento, Italy: University of Trento.

Lerner, Abba. 1943. "Functional Finance and the Federal Debt." Social Research 10 (1): 38-57.

Madigan, Brian F. 2009. "Bagehot's Dictum in Practice: Formulating and Implementing Policies to Combat the Financial Crisis." Speech at the Federal Reserve Bank of Kansas City's Annual Economic Symposium, Jackson Hole, Wyoming. http://www.federalreserve.gov/newsevents/speech/madigan20090821a.htm

McCulley, Paul. 2007. “Teton Reflections.” PIMCO Global Central Bank Focus, September. http:/www.pimco.com/EN/Insights/Pages/GCBF\%20August$\% 20$ September\%202007.aspx 
McKean, Roland N. 1949. "Liquidity and a National Balance Sheet." Journal of Political Economy 57 (6): 506-522.

Meaning, Jack and F. Zhu. 2011. "The Impact of Recent Central Bank Asset Purchase Programmes.” BIS Quarterly Bulletin, December.

Mehrling, Perry. 1998. The Money Interest and the Public Interest: American Monetary Thought, 1920-1970. Cambridge, MA: Harvard University Press.

— 2011. The New Lombard Street: How the Fed Became the Dealer of Last Resort. Princeton, NJ: Princeton University Press.

Meltzer, Allan H. 2010. "Learning about Policy from Federal Reserve History." Cato Journal 30 (2): 279-309.

Minsky, Hyman P. 1977. "The Financial Instability Hypothesis: An Interpretation of Keynes and an Alternative to 'Standard' Theory." Challenge 20 (1): 20-27.

— 1984. "Frank Hahn's Money and Inflation: A Review Article." Journal of Post Keynesian Economics 6 (3): 449-457.

Minsky, Hyman P. 1982. Can "It” Happen Again? Essays on Instability and Finance. Armonk, NY: M. E. Sharpe.

—. 1985. "Money and the Lender of Last Resort." Challenge 28 (1): 12-18.

_ 1986. Stabilizing an unstable economy. New York: McGraw Hill

—. 2008. "Securitization." Policy Note. Preface and afterword by L. R. Wray. Annandaleon-Hudson, NY: The Levy Economics Institute of Bard College.

Moe, Thorvald Grung. 2012. Terms and conditions for central bank liquidity support, manuscript

Mueller, Reinhold C. 1997. The Venetian Money Market: Banks, Panics, and the Public Debt, 1200-1500. Balitimore, MD: Johns Hopkins University Press.

Nersisyan, Yeva and L. Randall Wray. 2010. "The Global Financial Crisis and the Shift to Shadow Banking.” Working Paper No. 587. Annandale-on-Hudson, NY: The Levy Economics Institute of Bard College.

Nesvetailova, Anastasia. 2008 "Three Facets of Liquidity Illusion: Financial Innovation and the Credit Crunch." German Policy Studies 4 (3): 83-132. 
Perino, Michael. 2010. The Hellhound of Wall Street: How Ferdinand Pecora's Investigation of the Great Crash Forever Changed American Finance. New York, NY: The Penguin Press.

Pozsar, Zoltan. 2011. "Institutional Cash Pools and the Triffin Dilemma of the U.S. banking System." IMF Working Paper 11/190. Washington, D.C.: International Monetary Fund.

Pozsar, Zoltan, T. Adrian, A. Ashcraft, and H. Boesky. 2010. "Shadow Banking." Staff Report No. 458. Federal Reserve Bank of New York.

Pozsar, Zoltan and M. Singh. 2011. "The Nonbank-Bank Nexus and the Shadow Banking System." IMF Working Paper 11/289. Washington, D.C.: International Monetary Fund.

Sayers, Richard S. 1949. "Central Banking in the Light of Recent British and American Experience.” The Quarterly Journal of Economics 63 (2): 198-211.

Shirakawa, Masaaki. 2010. “Uniqueness or Similarity? Japan's Post-Bubble Experience in Monetary Policy Studies." Keynote address at the Second International Journal of Central Banking (IJCB) Fall Conference. Tokyo, Japan. September 16, 2010.

Singh, Manmohan and J. Aitken. 2010. "The (Sizable) Role of Rehypothecation in the Shadow Banking System.” IMF Working Paper 10/172. Washington, D.C.: International Monetary Fund.

Schwartz, Anna J. 1992. “The Misuse of the Fed's Discount Window.” Federal Reserve Bank of St. Louis Review.

Sheng, Andrew. 2011. "Central Banking in an Era of Quantitative Easing." Working paper No. 684. Annandale-on-Hudson, NY: The Levy Economics Institute of Bard College.

Stella, Peter. 2009. "The Federal Reserve System Balance Sheet: What Happened and Why it Matters.” IMF Working Paper 09/120. Washington, D.C.: International Monetary Fund.

Stella, Peter and A. Lonneberg. 2008. "Issues in Central Bank Finance and Independence." IMF Working Paper 08/37. Washington, D.C.: International Monetary Fund.

Tarullo, Daniel K. 2010. Comments on "Regulating the Shadow Banking System" at the Brookings Panel on Economic Activity, Washington D.C., September 17, 2010.

Thornton, Daniel L. 2008. "Walter Bagehot, the Discount Window, and TAF." Economic Synopses. Federal Reserve Bank of St. Louis.

_. 2010. "The Downside of Quantitative Easing." Economic Synopses. Federal Reserve Bank of St. Louis. 
Thornton, Henry. 1802. An Inquiry into the Nature and Effects of the Paper Credit of Great Britain. London: George Allen and Unwin.

Tucker, Paul. 2009. "The Repertoire of Official Sector Interventions in the Financial System: Last Resort Lending, Market-Making, and Capital.” Remarks at the Bank of Japan 2009 International Conference. Tokyo, Japan, May 27-28, 2009.

- 2010. "Shadow Banking, Financing Markets, and Financial Stability." Remarks at a Bernie Gerald Cantor (BGC) Partners Seminar, London, UK, January 21, 2010.

— 2011. Discussion of Lord Turner's Lecture, "Reforming finance: are we being radical enough?" Remarks at the Clare Distinguished Lecture in Economics. Cambridge, UK, February 18, 2011.

_ 2012. "National Balance Sheets and Macro Policy: Lessons from the Past." Speech at the Society of Business Economists' Annual Dinner. London, UK, February 28, 2012.

Turner, Adair. 2011. "Reforming Finance: Are We Being Radical Enough?” Remarks at the Clare Distinguished Lecture in Economics. Cambridge, UK, February 18, 2011.

Ugolini, Stefano. 2011. "What Do We Really Know about the Long-Term Evolution of Central Banking? Evidence from the Past, Insights for the Present.” Working Paper 2011/15. Oslo, Norway: Norges Bank.

Volcker, Paul. 2008. Remarks at a luncheon of the Economic Club of New York, April 8, 2008. http://galanto.com.br/pdf/080408volckerspeech.pdf

Yellen, Janet L. 2011. "The Federal Reserve's Asset Purchase Program.” Speech at the Brimmer Policy Forum, Allied Social Science Associations Annual Meeting. Denver, CO, January 8,2011

Wray, L. Randall. 1998. Modern Money Theory: A Key to Full Employment and Price Stability. Northhampton, MA: Edward Elgar.

_. 2011. "Minsky's Money Manager Capitalism and the Global Financial Crisis." Working Paper No. 661. Annandale-on-Hudson, NY: The Levy Economics Institute of Bard College.

Zorn, Lorie and A. García. 2011. "Central Bank Collateral Policy: Insights from Recent Experience." Bank of Canada Review, Spring. 